\title{
Notes on the vegetation of Suriname
}

\section{I- Vegetation changes in a dammed up fresh water swamp in NW Suriname ${ }^{*}$ )}

\section{P. A. Teunissen $\left({ }^{* *}\right)$}

\begin{abstract}
The vegetational changes in a newly dammed area on the Nanni Creek Basin in NW Suriname are here considered. The effects of periodical flooding on the different vegetation types are studied, and the types of succession ocurring at present are described. It is postulated that marsh forests that are now being drowned will be replaced by a Triplaris swamp forest. Peat levels will probably remain constant, as any accumulation of peat during high water seems to be counter-balanced by peat decomposition and destruction by fire during low water levels.
\end{abstract}

\section{INTRODUCTION}

The Nanni Creek in NW Suriname, approximately $150 \mathrm{~km}$ long, empties into the Corantijn River about $12 \mathrm{~km}$ south of the settlement of Nieuw Nickerie (fig. 1).

Because the Nanni drainage basin has, for the greater part, a swampy (') characteristic, and the creek itself is covered over a long distance with floating vegetation, the entire basin is usually called the Nanni Swamp. The Nanni Swamp is bordered in the north-west by the Nieuw Nickerie polder area $\left({ }^{2}\right)$, in the north-east by the lower Nickerie River, and it lies between the Corantijn River in the west, the Maratakka River in the east and continues south until the boundary of a higher landscape. The whole drainage basin covers an area of about $1700 \mathrm{~km}^{2}$.
Within the scope of a study on the Hydrological behaviour of shallow lakes and marshes in small watersheds in the humid tropics, with special reference to the Nanni Swamp in Suriname by Sevenhuysen $\left({ }^{3}\right)$, the present author studied the influence of the recently changed hydrological behaviour of the northern Nanni basin on the vegetation. Field work and aerial surveys in this area were carried out on May 25-26. July 29, 1972; Sept. 19-29 and Oct. 17-22. 1973; and Dec. 12-14, 24, 1974.

\section{ENVIRONMENTAL DESCRIPTION OF THE STUDY AREA}

In analyzing the factors influencing the vegetation in this part of Suriname, emphasis was placed on landscape $\left({ }^{4}\right)$, hydrology and fire. For general climatic data of Suriname see Braak (1935), Ostendorf (1953-1957), Lindeman and Moolenaar (1959), Schulz (1960), and the "Climatological tables" and "Precipitation maps" for Suriname by the Metereological Service, Paramaribo (1960). Comprehensi. ve climatological and metereological data from the Nanni area in particular will be dealt with by Sevenhuysen (in preparation).

\section{General description of landscapes}

The northern part of the Nanni Swamp is located in the recently formed (holocene) coastal region of Suriname. In holocene times marine, estuarine and riverain clays and loams

\footnotetext{
(*) - This investigation was financially supported by The Netherlands Foundation for the Advancement of Tropical Research (WOTRO).

(*) - Suriname Forest Service, Paramaribo, Suriname.

(1) - Swamps are areas where the soil stays moist to wet throughout the year and aeration of the soil is perma. nently impeded (Lindeman and Moolenaar, 1959).

(2) - Polders are impouded (impoldered) swampy areas, the water level of which can be regulated artificially for agricultural purposes.

(3) - R. J. Sevenhuysen, Agricultural University, Dept. of Irrigation and Drainage, Wageningen, Holland.

(4) - A landscape is an area that as a result of its specific geological origin morphologically forms a unit, characterized by a special rock formation, and a variety of soil conditions and vegetation, typical of this area (Van der Eyk, 1954, 1957).
} 


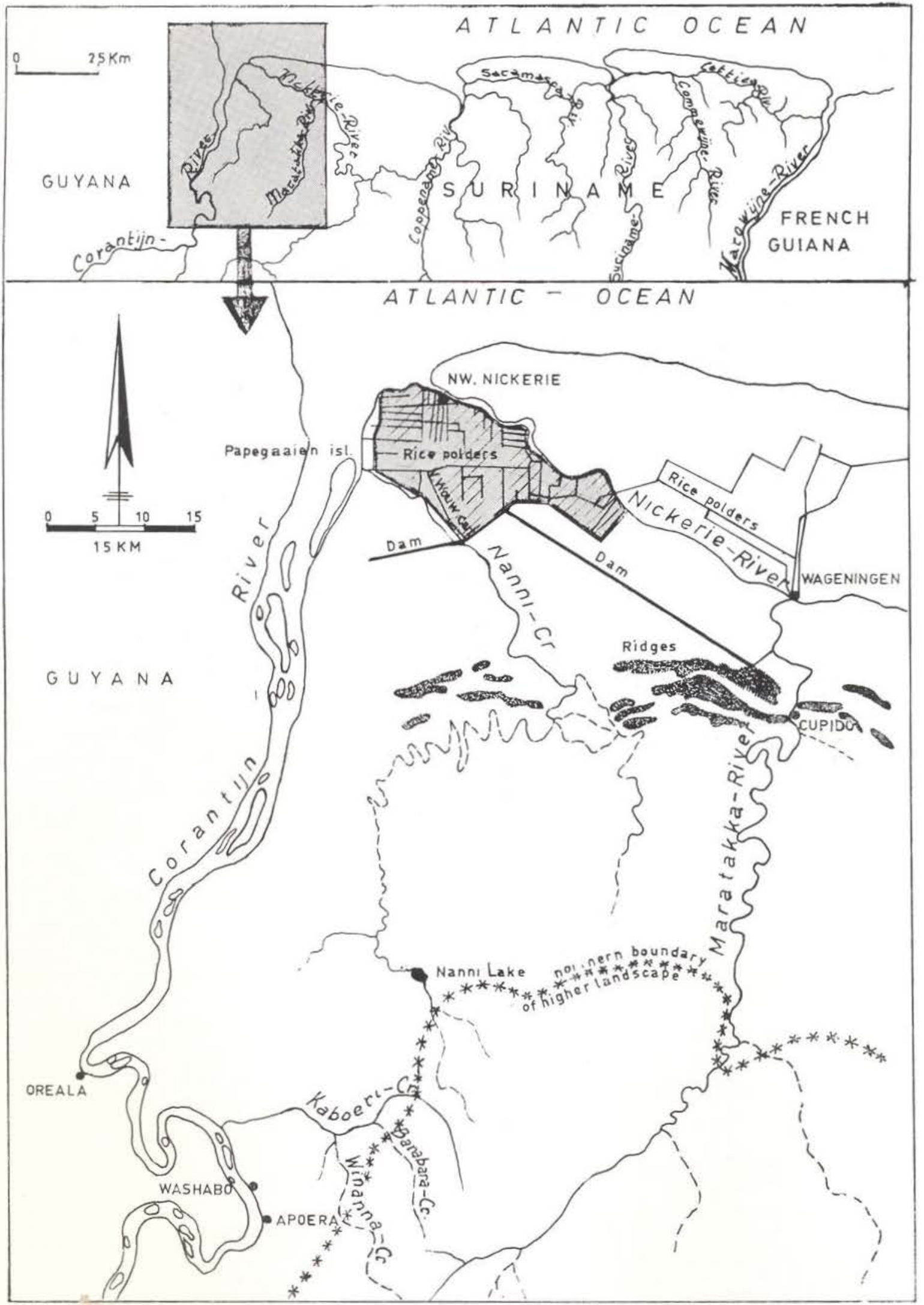

Fig. 1 - Nanni drainage basin and its location in Suriname (after Geyskes, 1973) 


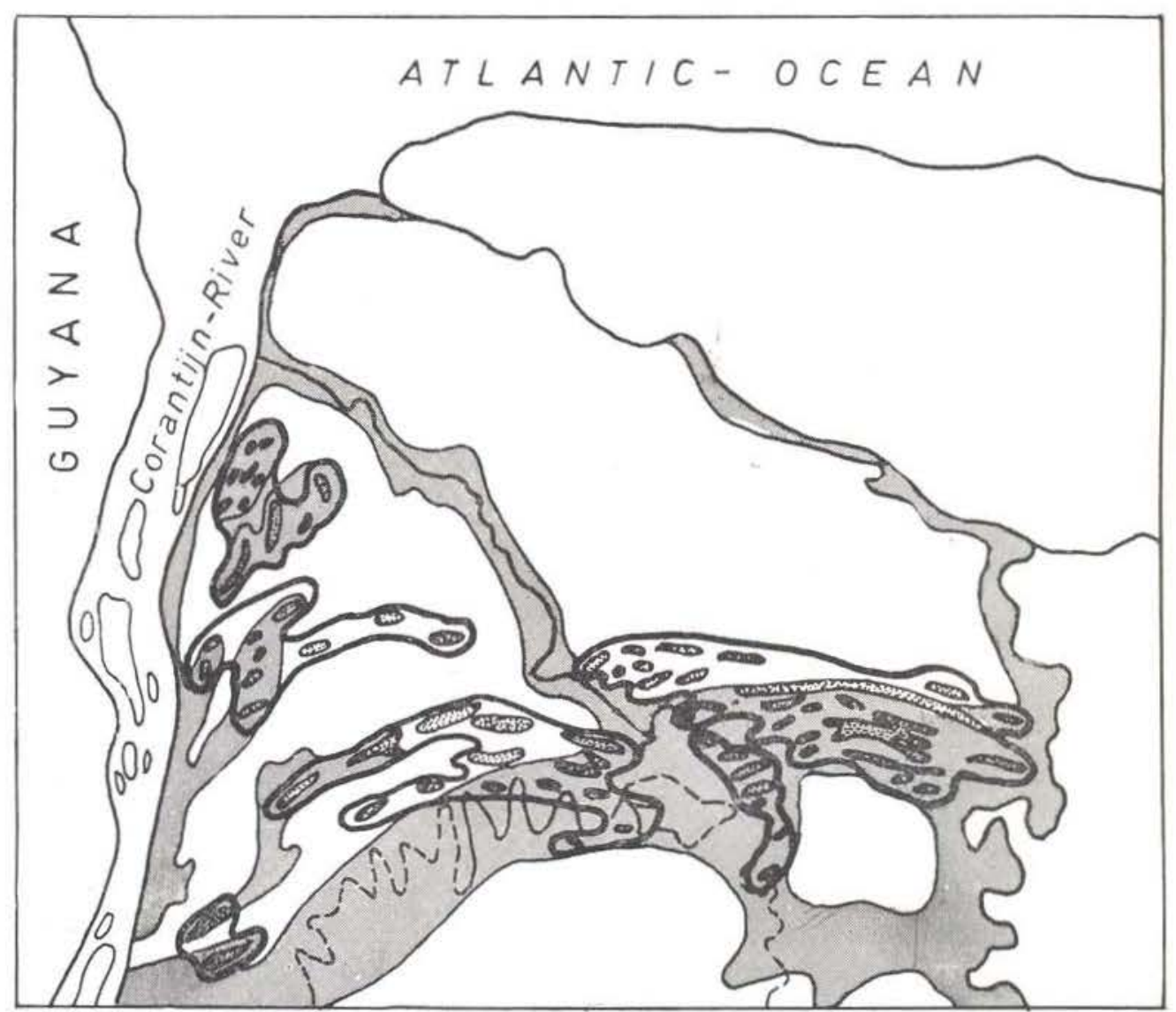

Landscapes:

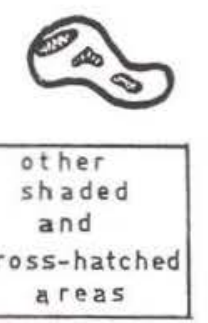

Kwatta landscape

Nickerie landscape

Soils: Ridge soils, Ridge flank soils and Feet soils

Fresh water clay swamp soils

Levee soils

Fig. 2 Main landscapes and soils of the norinern Nanni drainage basin (after van der Eky, 1957; Pons, 1964) 
alternating with sand and shell ridges were deposited on a pleistocene stratum (Brinkman and Pons, 1968).

Two landscapes can be distinguished in the northern Nanni basin (Van der Eyk, 1954, 1957): the Nickerie-landscape or Young sea and river clay landscape, and the Kwata-landscape or Ridge landscape (fig. 2).

\section{A. Nickerie-landscape}

The principal landscape element $\left({ }^{5}\right)$ is formed by vast swamps. The soils consist mainly of half ripened to nearly ripened clays, mostly without salt, to a depth of $1 \mathrm{~m}$ (Pons, 1964). The soils are covered with a peat $\left({ }^{6}\right)$ layer of abcut $10-30 \mathrm{~cm}$ thickness (DBK = Soil Survey Department Suriname, 1964).

These soils are classified as Fresh water clay swamps soils (DBK, 1964). Their vegetation consists of swamp forest, swamp wood, swamp scrub, or they are covered with a herbaceous swamp vegetation. Another landscape element is formed by marshy ( ${ }^{7}$ ) river levees along the Corantijn Nanni, Nickerie and Maratakka Rivers. The soils consist of neariy ripened and fully ripened fine sandy, silty and heavy clays. These soils are classified as River levee soils (DBK, 1964). Their vegetation is a river levee forest.

The last landscape element is formed by the periodically submerged mangrove belts alorig the lower rivers. The soils are brackish, slightly ripened clays. These are classified as Brackish periodically inundated clay swamp soils (DBK, 1964). These soils are covered by mangrove forest and swamp scrub.

\section{B. Kwatta-landscape}

Especially the southern and north-western part of the investigated area is formed by the Kwatta-landscape. The most important elements are fanshaped bundles of ridges: low dry and marshy bodies originated as coastal bars. The soils of the higher parts consist of dry fine sands, classified as Ridge soils (DBK, 1964). The marshy parts have soils of more or less heavy, fine sandy loam and are classified as Ridge flank soils and Ridge feet soils (DBK. 1964). Between the ridges interridgeswamps occur. Their soils are fresh water clay swamp soils and Levee Soils (DBK, 1964)

The higher parts of the ridges are as a rule, covered with ridge forest, the flanks and feet are covered with marsh forest, the interridge swamps have swamp forest, swamp wood, swamp scrub, or an open herbaceous swamp vegetation.

\section{HydROLOGY}

The whole Nanni area is hardly accessible and the creek itself is difficult and partly impossible to navigate because of heavy floating vegetation. Since early times the area has been visited only by some hunters, fishermen, balata-bleeders and woodcutters. Since 1915 the area around Nieuw Nickerie has been cultivated for rice growing. In the early twenties, people became interested in the Nanni swamp area as a water supply for their rice fieidis. In $1920 / 1921$, for the first time, a topographic survey of the Nanni Creek, from its mouth til! $55 \mathrm{~km}$ upstream, was carried out by topographer Sniphout (Geijskes, 1941). In 1926. at about $6 \mathrm{~km}$ from its mouth, the so called Boonacker Dam was built in the Nanni Creek to lead the water via the Roonacker Canal into the culture area (fig. 3 ). As this area has been enlarged several times since, frequently a water deficit occurred, especially with regard to the second rice harvest in relatively dry years. The water supply has been improved gradually.

In 1936 the whole drainage basin was surveyed by plane by irrigation engineer Van Wouw. In 1939 another reconnaissance flight was carried out by the airplane "Snip" of the Royal Dutch Airlines (KLM). During that trip

(5) - A landscape element is a smaller unit within a lan dscape. Landscape elements are strongly contrasting in topography, soils and vegetation (Van der Eyk, 1954, 1957).

(6) - Undecayed organic matter.

(7) - Marshy soils are inundated part of the year and in the other part they lie well above the ground-water table allowing aeration of the topsoil, but without dessication (Lindeman and Moolenaar, 1959). 


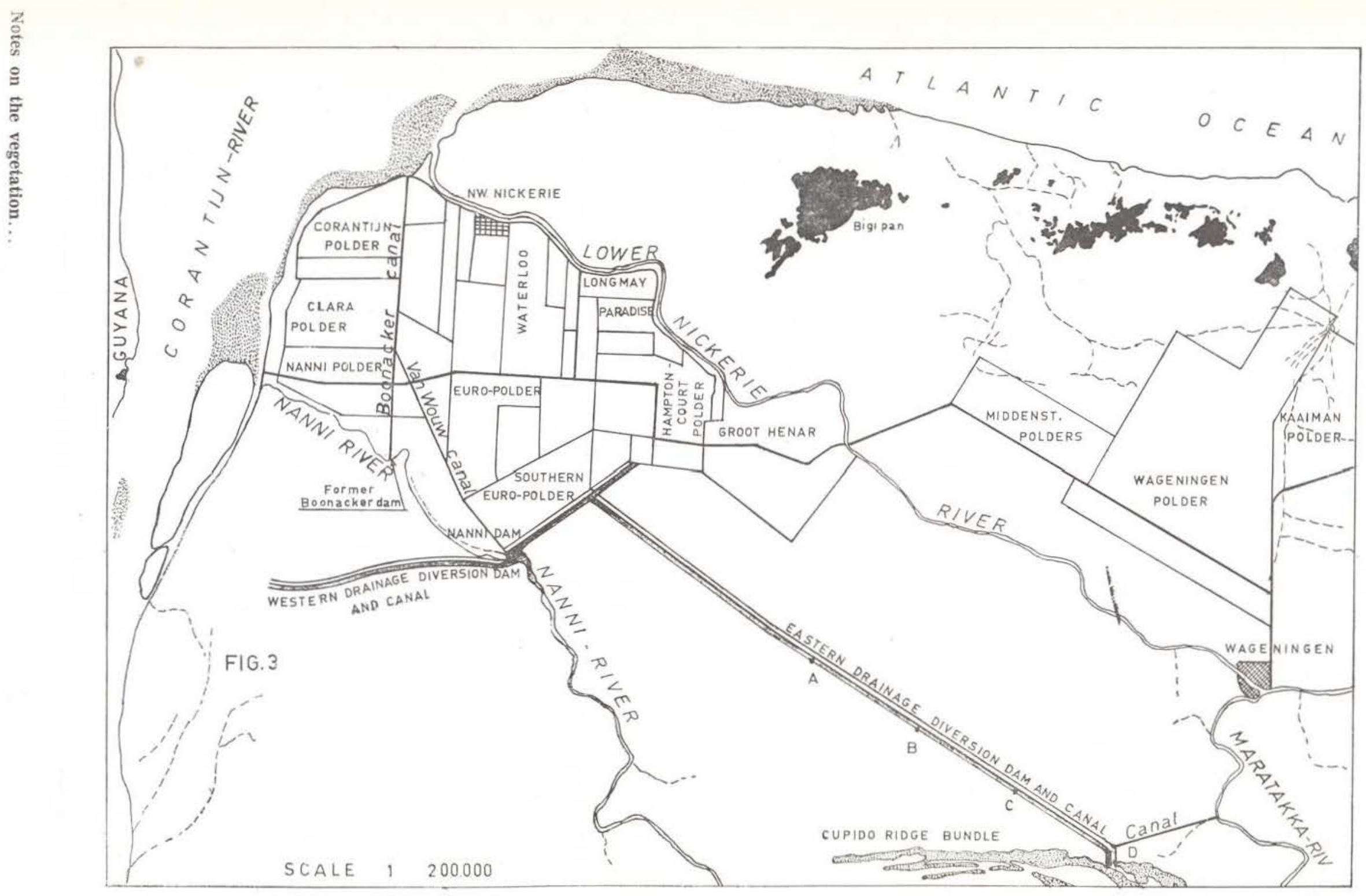

$\stackrel{\vec{N}}{\underline{\underline{N}}}$

Fig. 3 - Nickerie Polder Area and northern part of the Rani drainage basin. 
aerial photographs were taken of the higher course of the creek. From all these data the Irrigation Service of Nickerie designed a preliminary map of the entire Nanni basin. With the new information they built a new dam called "Nanni Dam" about $6 \mathrm{~km}$ further upstream to lead the Nanni water via the "Van Wouw" canal to the culture area. Construction of dam and canal was carried out in 1940/1942.

Because the swamp area is very fiat, from that time on part of the dammed up water drained away via the surrounding swamp into the lower course of the Nanni Creek while part of it disappeared east of the Nickerie polders into the Nickerie River. However. since 1942 there is evidence that the water level has been raised and somewhat stabilized.

Because the poider area was enlarged again, the Nanni Dam was improved in 1965 . after which a $11 \mathrm{~km}$ long "Lekbeteugelingsaam" (drainage diversion dam) was constructed) from the Nanni dam to the ridge complex of the Corantijn River, to prevent drainage into the lower Nanni River (photo 1). From that time on part of the dammed up water still drained away into the lower Nickerie and Maratakka Rivers. To prevent this, between 1971 and 1972 a final dam was built in an easterly direction, this time $33 \mathrm{~km}$ long. This new dam has improved the water supply considerably. For the first time since hydrological data are available (1956), the swamp level at the Nanni Dam rose above $+10.30 \mathrm{~m}$ Nickerie Level (N. P.) which means a water depth of $1.10 \mathrm{~m}$ above peat level for that lo. cation. The first period of this extremely high swamp level lasted 25 weeks (March 19September 9, 1972). At Nanni Dam maxima of +10.43 (1972),+10.53 (1973) and + $10.49 \mathrm{~m} \mathrm{~N}$. P. (1974) were recorded. See fig. 4 .

As an illustration of the recently changed hydrology of the northern Nanni basin, weekly water fluctuations of the swamp on both sides of point $A$ at the easterly dam (fig. 3) are given below (fig. 5). Fig. 4 and 5 show that

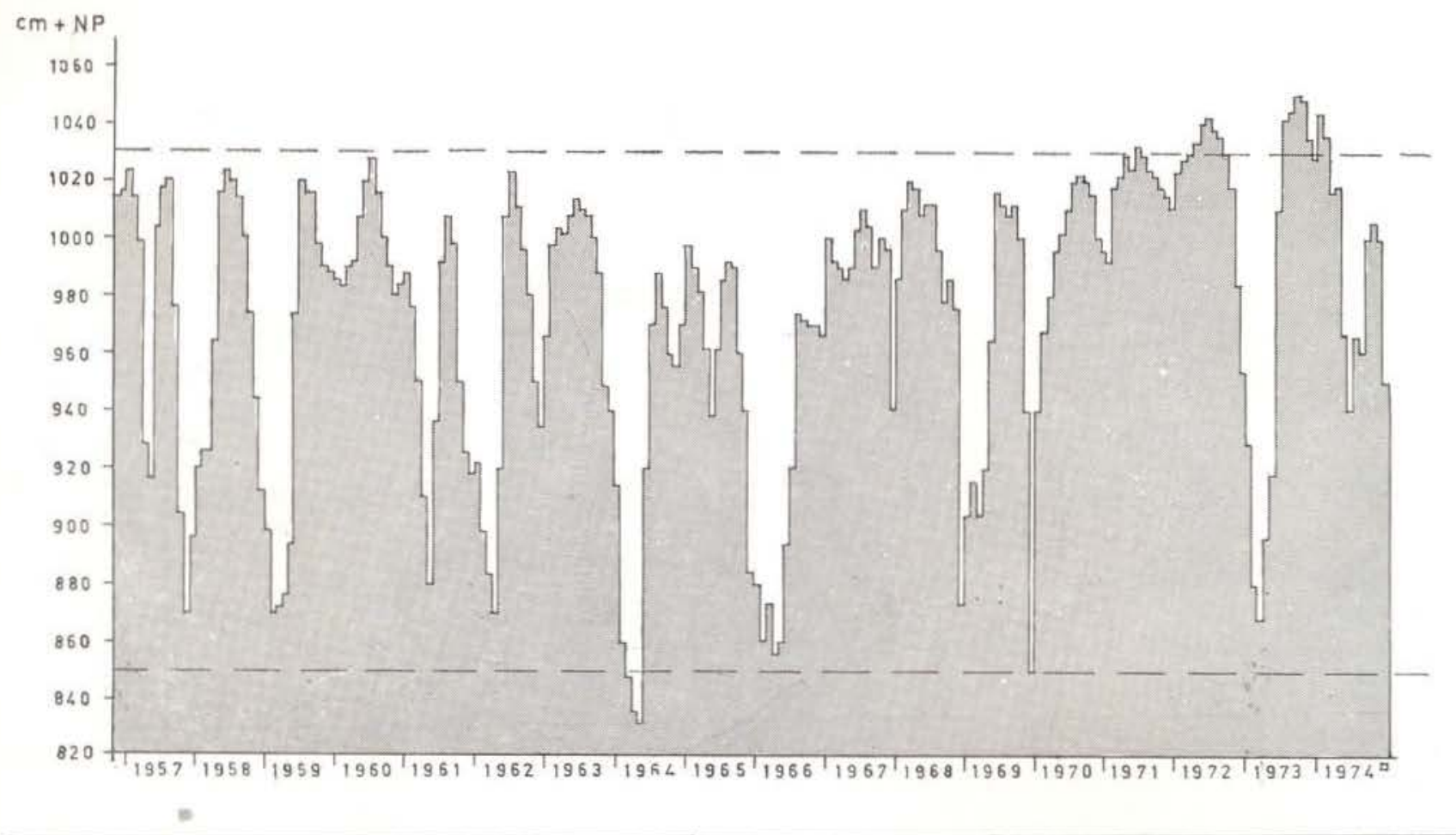

Fig. 4 Average monthly swamp level in $m+$ N.P. (Nanni Dam). Period 1957-1974, after figures supplied by the Suriname Hydrological Service, Paramaribo. 
in a relatively short time all dammed up water can be used for irrigation. At swamp levels lower than $+9.80 \mathrm{~m} \mathrm{~N}$. P. no optimal irrigation can take place for the entire culture area. At swamp levels lower then +9.20 $\mathrm{m} \mathrm{N}$. P. only the Nanni Creek bed still contains free water, while the peat layer of the surrounding swamp starts drying out (Sevenhuysen, personal communication).

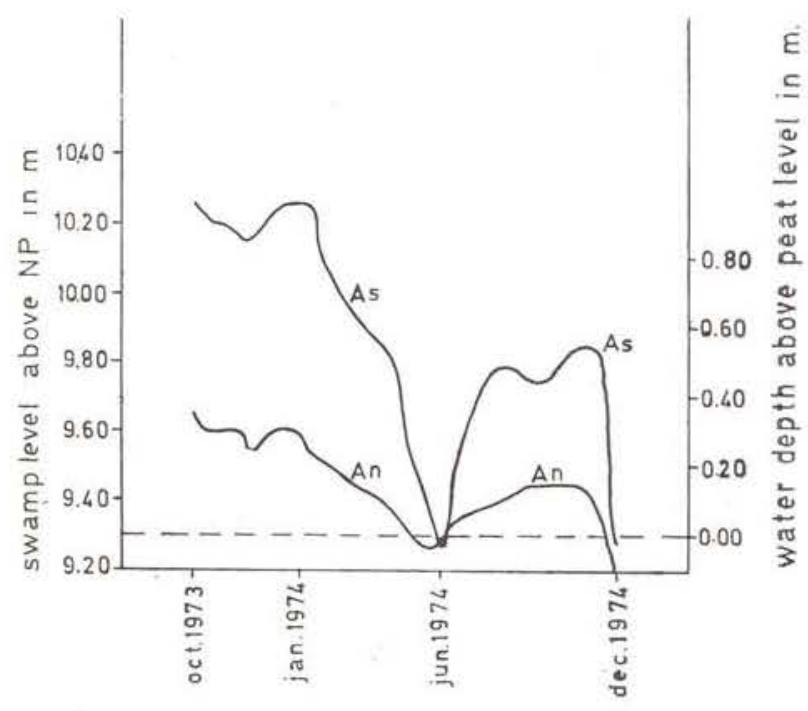

Fig. 5 Average weekly swamp levels and wattdepths (above peat level) at location A (fig. 3) inside (As) and outside (An) the Nanni drainage basin. Period October 1973-December 1974. After Sevenhuysen (in preparation).

\section{FIRE}

Primitive agricultural methods of the Amerindians, who during early times had been living on the higher ridges and levees around the swamp, could have caused burning of swamp vegetation in dry seasons, and of peat in extremely dry seasons. Since 1915 land along the northern edge of the Nanni Swamp is being reclaimed. A common method of removing vegetation and the peat layer from the land is by burning. These fires pushed by the ever present N.E. trade winds can easily move over a long distance. Since colo- nial times, hunters, fishermen, balata-bleeders and woodcutters have visited the areas and a few still do so at this time. To improve the navigability of the Nanni Creek, it is worthwhile trylng to burn the floating vegetation to the water level. This method can be especially successfull for grassy mats, which are mostly mixed with a lot of dead and dry material. This method was, and still is, being practiced Sometimes, for no particular reason except wiliful destruction, vegetation is burned. In severely dry periods even the peat layer can burn causing extensive swamp woods and swamp forest damage; this is not because of the burning of the trees but because of the loss of their root-substrate which will cause trees to fall over.

Bubberman (1973) mentions at least four severely dry periods since 190 's during which the vegetation, and also the peat layer, burned over large areas in northern Suriname.

Lindeman (1953) mentions that rather loose stands of herbaceous swamps south of the Nickerie River, near the Maratakka are fairly often destroyed by fire.

Bubberman (1973) reports peat and vege. tation fires in the northern part of the Nanni Swamp during the last extremely dry period in 1964. According to the figures of the Hydrological Service (Paramaribo) in 1964 the swamp level at Nanni Dam came below $+8.50 \mathrm{~m} \mathrm{~N}$. P., for the first time since hydrological data have been available (1956). The present author compared aerial photographs taken during 1947/1949 and $1971 / 1972$ of the northern swamp area. Between 1947 and 1972 about $55 \mathrm{~km}^{2}$ of closed swamp wood and swamp forest disappeared because of peat burns. These woods occurred scattered over the whole area in at least five different concentrations. It is very plausible that the peat layer also burned underneath the herbaceous swamp vegetation in between these woods and forests (see map of vegetation and vegetation changes in back flap) . 
The opinion is gaining ground that for most fresh water swamps in Suriname which are presently not covered with climax swamp forest, the vegetation has been developed after one, or repeated burns, by man.

\section{THE VEGETATION}

\section{EARLiER VEgEtATION STUDIES}

In 1933 Lanjouw (1936) visited the southern border of the Waterloo sugar plantation, and made the first botanical collection of the Nanni Swamp along its northern border. This part of the swamp, however, has now been impoldered.

On request of the Irrigation Service, Geijskes (1941, unpublished) tried to reach the source of the Nanni Creek in 1941, but because of the heavy floating vegetation from the 4 th hairpin turn ( $60 \mathrm{~km}$ upstreams) on, he was forced to return without reaching his goal. This trip however can be considered as the first terrestrial biological survey in the northern part of the Nanni drainage basin. In his report Geijskes gives an account of soil, vegetation, flora and fauna of the visited area. Some of his observations concerning flora ana vegetation were published later (Geijskes, 1945; Geijskes and Schols, 1948). A herbarium collection was made but partly unidentified material was distributed to herbaria abroad during the Second World War. From his 1941 trip, and aerial surveys in 1942 (Geijskes, 1942. unpublished) and 1946 (Geijskes and Schols, 1948), Geijskes sketched a vegetation map. scale 1:200.000, of almost the entire Nanni basir. (Geijskes 1946, unpublished). Geijskes placed his unpublished data at the author's disposal. They are used in this paper thanks to his kind permission.

Early in 1949 Lindeman (Lindeman, 1953: Lindeman and Moolenaar, 1955, 1959) visited the fresh water area south of the Nickerie River between the Nieuw Nickerie culture area and
Maratakka River. Lindeman recorded 29 vegetation plots in this area. Fourteen plots are now lost as a result of impoldering. A vegetation map was given. The vegetation types Lindeman (1953) distinguished, however, occur also in the now investigated, somewhat more southern area.

\section{Vegetation DEscription $\left({ }^{8}\right)$}

A short description of the vegetation of the northern part of the Nanni Swamp is given below, extracted from above mentioned sources.

Unpublished observations of Geijskes will be dealt with in more detail. The vegetation units described below are arranged according to the legend of the present map of vegetation and vegetation changes (see back flap).

\section{A. Mangrove forest, Machaerium lunatum (branti-makas and Hibiscus tiliaceus (maho) scrub}

Geijskes (1941) mentions Rhizophora mangle (mangro). Avicennia nitida (parwa) and Acrostichum aureum (tabaka-tiki) along the Corantijn River and Nanni Creek mouth. Lindeman (1953) finds Avicennia and Rhizophora upstream along the Nickerie River until Post Utrecht. Along the Maratakka River the last Avicennia tree was seen $5 \mathrm{~km}$ upstream, the last Rhizophora tree $10 \mathrm{~km}$ upstream.

Between the mangrove trees Machaerium lunatum (branti-maka) scrub exists along the Nanni Creek mouth (Geijskes, 1941) as wel! as along the Nickerie River and the Maratakka River where it does not quite reach the Amerindian village of Cupido (Lindeman, 1953).

Hibiscus tiliaceus (maho) scrub is mentioned by Geijskes (1941) from the Nanni Creek mouth and it was found by Lindeman (1953) in the Cupido-line.

(8) - For the convenience of those readers, who are not acquainted with scientific plant names, local names (if available) are added in brackets. A complete list of species mentioned in text and tables is given as Appendix I. 


\section{B. Herbaceous swamp vegetation}

Geijskes (1941) remarks that open swamps aiong the lower course of the Nanni Creek, that is from its mouth till the first hairpin turn, inave a similar vegetation as the swamps do south of the polders of Nieuw Nickerie. This vegetation consists of herbaceous plants in which the giant sedge Cyperus giganteus (pajagrasi) and Cyperus articulatus (adroen) dominate. According to Lindeman (1953), this type of vegetation which he describes as Cyperus giganteus-Typha-Scleria swamps, also occurs south of the Nickerie River. According to the dominance of one or a few species, he distinguishes various communities. Important species are Typha angustifolia (langa-grasi). Cyperus articulatus (adroen), Cyperus giganteus (paja-grasi) and Montrichardia arborescens (mokomoko). In some places shrubs and small trees appear in these swamps as a first sign of development into swamp wood and swamp forest (Lindeman, 1953).

Floating vegetation also exists, mainly in creeks. Lanjouw (1936) mentions some species of open water and of swamps near Nieuw Nickerie. For the lower course of the Nanni Creek, Geijskes (1941) describes floating vegetation which grows out from the banks and sometimes covers the total water surface. He mentions especially two "creek grass" species as dominant in these mats: "bamboe" grass with a loose panicle $\left({ }^{8}\right)$ and "soppoe" grass with a long closed panicle $\left({ }^{10}\right)$. As accompanying species he gives Ludwigia leptocarpa and L. nervosa and two species of "matrozenroos" one of which is Hibiscus sororius. Further, a dull lilac flowering Convolvulaceae ("perhaps Ipomoea subrevoluta") and locally a dark green herb named "Louisa or segodrowiwiri ( $\left.{ }^{11}\right)$ are noted. Geijskes also makes mention of "warapa" grass $\left({ }^{12}\right)$ from the mouth of Kamisa and Two Mouth Creeks. From the Nanni Creek further upstream he reports floating Montrichardia arborescens mokomoko) islands with accompanying shrubs and lianas, to which Allamanda cathartica (Wilkensbita) and Cydista aequinoctialis belong. Sometimes these islands contain Pterocarpus officinalis (watra-bebe) treelets as well. Between the islands floating mats of creek grasses are found again with Hibiscus sororius, both Ludwigia species and a Xyris species $\left({ }^{13}\right)$. The more open patches are covered with Hydrocotyle umbellata (waternavel), Nymphoides humboldtianum and in a few cases with Lentibulariaceae spp.. Lindeman and Moolenaar (1959) also make mention of the floating mats in the Nanni Creek. They report that these mats sometimes form a solid floating peat layer up to $2 \mathrm{~m}$ thick, which occurs over considerable stretches of the creek.

\section{Swamp scrub}

Swamp scrub is not distinguished by Linde. man (1953) as a separate vegetation type. Lindeman iricludes swamp scrub with his swamp wood, of which he gives the following definition: 10-15 $\mathrm{m}$ high vegetation without distinct stratification of the trees. Swamp scrub is defined here as a woody swamp vegetation consisting predominantly of shrubs ranging in height between 2 and $5 \mathrm{~m}$. It is an intermediate stage between open herbaceous swamps with scattered shrubs and treelets, and swamp wood, which is defined here as a low, open to closed, one story forest, 5-15 m high.

In species composition swamp scrub has an intermediate position between open herbaceous swamps and (low) swamp wood.

\section{Swamp wood and swamp forest}

Lindeman (1953) mentions open swamp wcods south of the Nickerie River. These open woods have a dense undergrowth ciosely rela-

The following suggestions are made based upon recent field observations by the present author:

(9) - Luziola spruceana.

(10) - Sacciolepis striata and/or Hymenachne amplexicaulis.

(11) - Dianthera obtusifolia.

(12) - Laersia hexandra.

(13) - probably Xyris macrophala. 
ted to the vegetation of the open swamps in the vicinity, often with numerous vines (Lindeman and Moolenaar, 1959).

Erythrina (kofimama) woods and groves are mentioned by Geijskes (1941) as existing in the area south of the polders. Besides these, Lindeman also (1953) reports and maps woods of this type south of the Nickerie River. Mixed swamp woods, mainly consisting of Pterccarpus officinalis (watra-bebe) and Tabe. buia insignis (zwamp-panta), and also richer forms with Triplaris surinamensis (mira-oedoe), Annona glabra (zwamp-zuurzak) and Ficus spp. have been described from the area south of the Nickerie River between Corantijn and Maratakka River. Triplaris surinamensis (mira-oedoe) - Bonafousia tetrastachya (kapoewatiki) swamp forest (Lindeman and Moolenaar, 1953, 1959) is mentioned by Lin deman (1953) as existing along margins and in depressions of high ridges, on fragments of low ridges, and levees around Nickerie. Lindeman and Moolenaar (1959) mapped Symphonia globulifera (mataki) - Virola surina. mensis (baboen) forest south of the Cupido ridge bundle.

\section{E. Marsh or seasonal swamp forest}

Geijskes $(1941,1946,1948)$ reports these forests along the lower course of the Corantijn River; from the Nanni Creek mouth till the Boonacker Dam; from Kaaiman Creek and the mouths of Kamisa and Two Mouth Creek. Most of the tree species Geijskes reports from these levees are characteristic for this type of forest: Carapa procera (krapa), Ceiba pen tandra (kankantri), Triplaris surinamensis (miraoedoe), Manilkara bidentata (boletri), Cordia tetrandra (tafrabon), Tabebuia insignis var. monophylla (zwamp-panta) and the palms Attalea maripa (maripa) 2), Euterpe oleracea pina) and Desmoncus spec. (bamba-maka). From the middle course of the Nanni Creek (hairpin turns section) Geijskes reports a richer form of marsh forest, and he adds the following species: Mora excelsa (mora). Eschweilera sp. (barklak), Tabebuia serratifo. lia (groenhart), Cedrella odorata (ceder),
Bactris spec. (keskes'maka) and Heliconia bihai (paloeloe). The trees had flood marks on the trunks at one foot high. Lincieman (1953) makes mention of marsh forest from marshy strips between the drier parts of the Cupido ridge and the levees of Nanni Creek, Maratakka and Nickerie River.

\section{F. Ridge forest}

The real ridge forest, a poor form of tropical rain forest, is reported by Lindeman (1953) as found on drier parts of the ridges west of the Maratakka River near Cupido.

3. Vegetation map 1972 (see map in back flap)

After some additional field work and aerial surveys the above mentioned vegetation units (A-F) were mapped at the present scale $1: 100.000$ from aerial photographs scale 1:30.000 infrared (1972). Legend:

A: Mangrove forest, Machaerium lunatum (branti-maka) and Hibiscus tiliaceus (maho) scrub.

B: Rooting herbaceous swamp vegetation, mainly consisting of the Cyperus giganteus (paja-grasi) - Typha (langa-grasi) Scleria (baboen-nefi) type and floating herbaceous swamp vegetation.

C: Swamp scrub.

D: Swamp wood: Erythrina (kofimama) woods and groves (ER); Pterocarpus (watra-bebe) - Tabebuia (panta) woods (PT) and swamp forest: Triplaris (mira-oedoe) - Bonafousia (kapoewa-tiki) forest and Symphonia (mataki) - Virola (baboen) forest.

E: Marsh or seasonal swamp forest.

F: Dryland ridge forest.

This map is also used to show the burned forest areas (period 1948-1972), and drowned forests (period 1941-1972, 1972-1974). 
A more detailed vegetation map of the whole Nanni drainage basin will be published in the near future in the framework of an inventory of ecosystems in Suriname for the purpose of nature conservation policy.

\section{VEGETATION CHANGES}

\section{Vegetation Changes 1941-1972}

Studying the already mentioned literature, vegetation maps and aerial photographs of the area, considierable changes in vegetation were found to have taken place between 1941 and 1972, mostly caused by fire (swamp wood and swamp forest), but also by changes of the hydrological behaviour of the swamp (marsh forest).

Geijskes (1946, unpublished) sketched some levee forests along the Nanni Creek and close to the Kaaiman Creek mouth, all between the Nanni Dam and the hairpin turns. For the greater part these levee forests were drowned within the period 1941-1972. These forests have been mapped (see map in back flap) . Their total area is estimated at about $5 \mathrm{~km}^{2}$. Photo 1 shows part of the drowned river levee close to the Nanni Dam where the forest has disappeared completely.

\section{Vegetation changes, 1972}

On May 25, 1972, after the eastern drainage diversion dam was completed, a boat trip was made through the excavation canal along this dam from the Maratakka River to the Nickerie polder area. During this trip the leved of the swamp at Nanni Dam was extremely high $(>+10.30 \mathrm{~m} \mathrm{~N}$.P.) and had been for about $51 / 2$ weeks. At that time the swamp woods south of the dam were dying. Subsequent tc this trip the Nanni Creek was visited from the Nanni Dam up to the Kaaiman Creek mouth. At one place the river was fringed by a narrow strip of dying levee forest. Only some Cordia trees and Attalea maripa palms seemed to survive. The levee forest at Kaaiman Creek was also dying.

In July of the same year the author joined a reconnaissance flight over the Nanni basin. The visible effect of the constructon of the eastern dam on the vegetation appeared to be limited to the northern part of the drainage basin, i.e. the area north of the Nanni Creek hairpin turns. In that area a lot of swamp scrub and wood and marsh forests (on levees and along the northern edge of the Cupido ridge bundle) were dying. However, along the western part of the dam the swamp woods looked rather healthy on both sides. Here the swamp woods, as was found out later, grow on a somewhat higher elevation. Herbaceous vegetation in between the drowned woody vegetations looked healthy.

\section{Vegetation changes 1973-1974}

In April, 1973, WOTRO placed funds at the author's disposal to study the vegetation changes in detail. In September, 1973, the combined hydrological-vegetational study of the Nanni basin could start.

\section{Selection of sample plots}

Along both sides of the eastern drainage diversion dam plots were selected, the study of which could give an idea of the vegetation changes which took place in the past $1 \frac{1 / 2}{2}$ years. Herbaceous swamp vegetations and swamp scrub were excluded from the study as they form a very irregular mozaic on both sides of the dam. It could not be justified to assume that these vegetations on both sides of a certain point at the dam were identical at the time the dam was closed. It was considered too late to study probable changes in these types of vegetation. Selection of plots was done during a few trips in an air-propeller boat. From the highly elevated chairs it is easy to look over the dam. Three "types" of swamp wood and one type of marsh forest could be then recognized.

Along the western part of the dam:

A. High Pterocarpus-Tabebuia swamp woods

Along the central part of the canal:

B. Low Pterocarpus-Tabebuia swamp woods (in between Pterocarpus-Tabebuia swamp scrub and herbaceous swamp vegetation) . 
Along the eastern end of the canal:

C. Erythrina swamp woods (in between herbaceous swamp vegetation).

\section{Marshy ridge forest.}

On pair of sample plots (one plot inside and one outside the dammed up swamp, and opposite to each other) was chosen in each of these types as follows. With the aid of the aerial photographs taken in 1972 a unit of each vegetation type was chosen which looked homogeneous in structure, texture and grey tone, and which was intersected by the dam. Within each unit a sample plot was chosen. This was considered the most justified method of selecting pairs of sample plots which were very probably comparable at the time the dam was constructed and closed. In this way the following plots were selected:

A. Pairs A s (= south) and A n (= north) in $\pm 12 \mathrm{~m}$ high Pterocarpus-Tabebuia swamp wood.

B. Pairs B s and B $n$ in low ( $\pm 6-8 \mathrm{~m}$ ) Pterocarpus-Tabebuia swamp wood.

C. Paris $\mathrm{C} s$ and $\mathrm{C} n$ in a more or les closed Erythrina swamp wood $\pm 8 \mathrm{~m}$ high.

D. Pairs $D$ w (= west) and $D$ e (= east $)$ in closed marshy ridge forest.

For location of these plots see vegetation map in back flap.

\section{Sample method}

In September, and October, 1973 all plots were sampled as well as possible. At that time, access to the plots inside the dammed swamp was rather difficult because, in addition to the discomfort caused by clouds of mosquitoes, the area was covered with a mixture of dead wood, floating pegasse, and water reaching to breast or shoulder height (see photo 4). In each plot, far enough from the zone influenced by the vegetation of the dam and the excavation canal, a spiral tra. jectory was walked outwardbound until no new species were observed. The area seen in this manner varied in extent from $100 \mathrm{~m}^{2}$
(Erythrina swamp wood) to $800 \mathrm{~m}^{2}$ (marsh forest). From the plots the following data were collected:

a. Number and date of record.

b. Stratification.

In each plot outside the dammed up swamp the following strata have been distinguished: one or two tree layer (s), a shrub-layer. a herb-layer, a layer of rooting and/or floating aquatics (if any). In each plot inside the storage basin: one or two tree-layer(s), a shrub-layer, a layer of plants rooting in floa. ting peat and/or on dead wood and a layer of rooting and/or floating aquatics. In all layers, epiphytes, lianas and vines reaching those layers were included.

c. Heigth in $\mathrm{m}$ and $\%$ of coverage

d. List of species per layer

c. Frequency of each species using the following scale :

$$
\begin{array}{ll}
\mathrm{D}=\text { Dominant } & \mathrm{f}=\text { frequent } \\
\mathrm{Cd}=\text { co-dominant } & \%=\text { present } \\
\text { va = very abundant } & +=\text { scarce } \\
\mathrm{a}=\text { abundant } & \mathrm{U}=\text { seen outside } \\
& \text { sample plot }
\end{array}
$$

f. Growth form and/or growth stage of each species :

$$
\begin{array}{rlrl}
\mathrm{tr} & =\text { tree } & \mathrm{fe} & =\text { fern } \\
\mathrm{pm} & =\text { palm } & \mathrm{ep}=\text { epiphyte } \\
\mathrm{sh}=\text { shrub } & \mathrm{pa}=\text { parasite } \\
\mathrm{he}=\text { herb } & \mathrm{vi}=\text { vine (herba- } & \text { ceous) } \\
\mathrm{gh}=\text { giant herb } & \mathrm{li}=\text { liana (woody) } \\
\mathrm{gr}=\text { graminoid plant } & \mathrm{aq}=\text { aquatic } \\
\mathrm{sl}=\text { seedling } & \dagger=\text { dead } \\
\mathrm{jv}=\text { juvenile } &
\end{array}
$$

g. Water depth, peat thickness in $\mathrm{cm}$

h. Oblique aerial photographs and terrestrial photographs were taken.

If necessary, plant specimens were col. lected for identification and herbarium study. Two almost complete sets were collected, of which the first has been deposited in the Herbarium of the Surinam Forest Service in Paramaribo and the other in the Botanical Museum and Herbarium of the State University of Utrecht. 


\section{Description of sample plots}

The vegetation plots were described and compared for the first time during the period of September-October, 1973 (see tables A-D). In December, 1974, another visit was paid to the plots. In the meantime changes have been described below.

\subsection{Swamp wood}

The vegetation changes which took place in $A S, B$ S and $C S$ are well illustrated by comparing tables and photos of $A s$ and $A n$ (Table A, photos 2-5), B s and B n (Table B, photos 6-9) and $C s$ and $C n$ (Table $C$, photos 10-13) .

In this description all three plot pairs are considered together as the noticeable changes are rather similar, especially in the shrub-layer and lower layers.

\section{a. Tree layers}

In plot A s most Pterocarpus (watra-bebe: and Tabebuia (zwamp-panta) trees survived but crowns became partly deciduous during high water levels (photo 3 ). About $10 \%$ of these trees fell over (photo 5) during the period of observation (September 1973) - December 1974), possibly by weakening of the clay and peat layer in which they root. From the fallen trunks new shoots (photo 3 ) were observed in December, 1974. In plot B s almost all Pterocarpus and Tabebuia treelets died immediately.

In $\mathrm{C}$ s the dominating Erythrina (kofimama) trees survived although their crowns lost many leaves during high water levels (photo 10 and 11). Some trees fell over but immediately started to make new robust suckers in an explosive way, just like fallen Erythrina trees react after a peat fire when they also fall over. Also root suckers played a role in the ultimately developed, dense undergrowth (photo 12). Trees which still stood upright have survived in another way. Around the trunks, at the height of the high water leve!, floating, corky breathing roots (pneumatophores) were observed in October, 1973 (photo 13). These roots bent down during lower water levels and developed as prop roots, which were seen for the first time in December, 1974 (photo 14). Triplaris (miraoedoe). Virola (baboen) and Cecropia (boesipapaja) trees survived extreme inundation very well. A Ficus tree fell over. Euterpe (pina) palms died after a struggling year with only a few leaves left. Eight species of opiphytes, Philodendron linnaei, Philodendron cf. acutatum, Philodendron pedatum, Philodendron jenmanii, Monstera obliqua, Monstera cf. expilata, Monstera 14472 and Syngonium vellozianum var. poeppigii (all Araceae) were found on both sides of the dam therefore they survived very well. Not so with the lianas Entada polystachya and Dioclea virgata (pikinkaw-ai), as they were not seen in the dammed up swamp.

\section{b. Shrub layer}

Montrichardia arborescens (mokomoko) and Heliconia marginata (paloeloe) survivea high inundation; they were recorded on both sides of the dam. Between September/October. 1973 and December, 1974, Montrichardia ar. borescens stems in A $\mathrm{s}$ and B s seemed to have increased somewhat as well in number as in height. In C s, however, Montrichardia received strong competition from new Erythrina glauca (kofimama) shoots (photo 12). Four species of the scrub layers from northern plots: Costus arabicus (sangrafoe), Piper divaricatum and the ferns Acrostichum danaeifolium (tabaka-tiki) and Thelypteris serrata were not recorded from the southern plots. Epiphytes recorded on both sides of the dam are: Peperomia elongata var. piliramea (second record from Suriname) and Margravia coriacea One unknown vine recorded in the northern plots was not seen in the southern ones.

\section{c. Herb layers}

Thirteen species were recorded in the northern plots: Euterpe (pina) seedlings, Heliconia psittacorum (popokai-tongo), Ischnosiphon sp. (warimbo), the grass Panicum frondescens, the ferns Nephrolepis biserrata and Blechnum serrulatum, the vines Paullinia 
pinnata (fefifinga), Cissus sicyoides, four unidentified species and the epiphyte Polypodium ciliatum. Most of these species root from around and between Euterpe stems and Pterocarpus (watra-bebe) buttress roots. This shade-loving herb layer is completely absent in the sunny, drowned southern plots.

\section{d. Layer of plants rooting on floating peat and/or dead wood}

In the southern plots this new layer had developed instead of a herb layer as cescribed in c. Only the vine Paullinia pinnata (fefifinga) and the fern Nephrolepis biserrata were found in both the herb layer of the northern plots, and this new layer in the southern ones. All other species found on floating pegasse and/or dead wood are new helophytic pioneers (20 especies). Three shrubs are recorded: Hibiscus bifurcatus (jorka-okro), Solanum stramonifolium (bolomaka) and Ficus citrifolia. Furthermore, five broad-leaved herbs were noted: Pluchia odorata, Dianthera obtusifolia (segotrowiwiri), Heliconia sp. nov. nr. 14484 (paloeloe), Aes. chynomene sensitiva, Ludwigia affinis, the ferns Thelypteris serrata, the sedges Cyperus haspan, Cyperus pseudodistans, the giant grass Panicum grande and two creek grasses Luziola spruceana and Hymenachne amplexicaulis. This vegetation is strangled with vines, of which five species were recorded: Phaseolus campestris, Ipomoea tiliacea (patata-tite), Gurania spinulosa, Funastrum clausum and Melothria fluminensis (sneki-komkomro).

\section{e. Layer of aquatic plants}

A few specimens of three species of floating aquatic plants, the Nile lettuce Pistia stratiotes, and two species of duck weed Spirodela biperforata and Lemna minor, were found in northern plots. Pistia has especially developed explosively in southern ones. Together with the above mentioned species and Salvinia auriculata, Wolfiella lingulata and a few specimens of Ceratopteris thalictroides there, it forms a dense layer on the water surface not occupied with floating pegasses and dead wood. The water lily, Nymphaea blanda, has not been recorded from the southern plots.

The thickness of the peat layer in the northern, as well as in the southern, sample plots amounted to $30 \mathrm{~cm}$. The fluctuation of tne water level and water depth (above peat layer) for plot $A \mathrm{n}$ and $\mathrm{A} s$ are given in fig. 5 . The fluctuations are similar for plot pairs $B$ and $\mathrm{C}$, with the restriction that during high water levels the water in $B \mathrm{~S}$ and $\mathrm{C} s$ is estimated to be $5-15 \mathrm{~cm}$ deeper than in $A \mathrm{~s}$, due to the former watershed between the Nanni Creek and the Maratakka River; this is also caused by the inclined water surface going down in the direction of the Nanni Dam.

To find out why some swamp woods within the Nanni storage basin still do not seem to be intluenced by the new hydrological behaviour, a healthy looking Pterocarpus Tabebuia swamp wood along the western part of the canal was visited. The swamp wood appeared to grow on a somewhat higher elevation (20-40 cm measured).

\subsection{Marshy ridge forest}

The vegetation changes in D $\mathrm{w}$ are illustrated in Table $D$ and photo 14-17. Inside the dammed up swamp (D w) most trees from both tree-layers died, such as Manilkara bidentata (boletri), Spondias mombin (mope), older Carapa (krapa) trees and Euterpe (pina) palms. For other trees in D w it was too late to recognize individual species during the first visit in September, 1973. Trees such as Ceiba pentandra (kankantri), the palm Attalea maripa (maripa), young Carapa (krapa) individuals, Rinorea pubiflora and Gustavia (konikonioedoe) treelets barely survived the first long period of inundation. Triplaris surinamensis (mira-oedoe) and Cecropia obtusa (boesi-papaja) resisted it very well. New Triplaris seedlings came up, just as often happens when a swamp forest is destroyed by peat fire. A new shrub and herb-layer developed, tangled with twiners. Ipomoea phillomega (patatatite) developed explosively and by December, 1974, it covered almost the entire herb and shrub-layer and even the dead trees (photo 17). 
Triplaris surinamensis (mira-oedoe) seedlings, however, were able to compete with the new herbs and tanglers. After 13 months the young Triplaris trees already measured up to 3 meters in height (photo 17). The floating aquatics observed in October, 1973, were not seen again in December, 1974.

In May, 1972, the water depths ranged from $65-115 \mathrm{~cm}$ depending on the distance to the ridge crest. In October, 1973, water depth varied from 40-90 $\mathrm{cm}$. In May, June and December, 1974, the soil fell dry.

\section{MAPPING OF AtTACKED AND NROWNED VEGETATION}

From aerial surveys the area containing the attacked and drown swamp scrub, swamp wood, swamp and marsh forest is sketched in the vegetation map (in back flap). Within this area of $190 \mathrm{~km}^{2}$ about $10 \mathrm{~km}^{2}$ of marsh forest drowned while another $60 \mathrm{~km}^{2}$ of swamp scrub, swamp wood and swamp forest were severely attacked, or even died.

\section{FUTURE VEGETATION DEVELOPMENT AND PEAT GROWTH}

There are indications that recently drowned marsh forests (now $10 \mathrm{~km}^{2}$ ) will be succeeded by Triplaris (mira-oedoe) swamp forest.

Most attacked swamp forests (now $60 \mathrm{~km}^{2}$ ) will not survive because mature trees are starting to fall over while the natural tree regeneration is being drowned. A new herbaceous or shrubby swamp vegetation will possibly develop from this vegetation. Nothing can be said of the speed of vegetational succession towards the new climax: possibly a two-story swamp forest on a thick peat layer.

Vegetational succession is accompanied by peat growth. Since early times, during severely dry periods, the vegetation was damaged locally, and peat was decomposed by fire. This brought the vegetation back to earlier stages of development, while it deepened the swamp and increased the water-storage capacity of the basin.
Future peat growth depends on future water fluctuations which can be managed now to a certain degree.

a. After a few weeks with swamp levels lower than $+8.50 \mathrm{~m} \mathrm{N.P.} \mathrm{(at} \mathrm{Nanni} \mathrm{Dam)}$ the upper peat layers dry out to such an: extent that their rapid destruction by fire becomes possible.

b. At swamp levels lower than $+9.20 \mathrm{~m}$ N.P. decomposition of accumulated peat can take place by aerobic organisms.

c. At swamp levels between $+9.20 \mathrm{~m} \mathrm{~N}$.P. and $+10.30 \mathrm{~m} \mathrm{~N}$.P. litter will accumulate and turn into peat.

d. After a few weeks with swamp levels higher than $+10.30 \mathrm{~m}$ N.P. a quick accumulation of debris can take place as more woody vegetation dies which causes an extra quantity of organic matter to fall into the water.

Recapitulating, it can be said that peat growth will be in balance with peat decomposition if decomposition by fire and living decomposers during low water levels $c<+$ $9.20 \mathrm{~m} \mathrm{~N}$.P.) compensates for peat accumulation during high water levels $(>+9.20 \mathrm{~m}$ N. P.) .

Only if the swamp level will fluctuate around $+9.20 \mathrm{~m} \mathrm{N.P.} \mathrm{for} \mathrm{approximately}$ equal time periods above or below this level, and if levels $>+10.30 \mathrm{~m} \mathrm{N.P}$. can be avcided, peat accumulation and decomposition will be in balance. Because this will not be quite desirable for the water supply, in the long run a net peat growth has to be expected. This peat growth can be measured in permanent plots. If necessary and in a justified way peat growth can be nullified only by controlled burning.

\section{ACKNOWLEDGEMENTS}

This investigation was financially supported by the WOTRO-Foundation. I am much indebted to the Suriname Forest Service for all assistance given during the fieldwork and the preparation for publication of this article. I would like to thank the following persons: Ir. 
F.C. Bubberman and Dr. J.P. Schulz for their permission to cooperate in the hydrologicai project; Drs. M.C.M. Teunissen-Werkhoven and Ms. C.J. Vreden of the herbarium for their assistance in the field as well as for most taxonomical identifications; Mr. R.O. de Graav and his staff for drawing the illustrations and Mr. R.N. Kromoidjojo for his photographic work.

I would like to express my special thanks to Dr. D. C. Geijskes of the Rijksmuseum van Natuurlijke Historie at Leiden, Holland, for his willingness to place his manuscripts, maps and photographs at my disposal; also to the Staff of the Botanisch Museum en Herbarium of the State University of Utrecht, Holland for additional plant identifications. The manuscript was kindly reviewed by $\mathrm{Dr}$. J. C. Lindeman.

I am greatly indebted to Ir. R.J. Sevenhuysen for the fruitful cooperation and to his wife for her Nickerian hospitality. Finally I thank Mr. H. A. Reichart M. Sc. for the correction of the English text.

\section{RESUMO}

O pântano de Nanni, no Suriname, é uma área natural, medindo $1700 \mathrm{~km}^{2}$. Segundo os dados disponíveis, a vegetação e a camada turfosa têm sido fortemente influenciadas pelo fogo. A partir do início deste século, J pântano vem sendo usado como fonte de abastecimento de água para a área de rizicultura que circunda a vila de Nieuw Nickerie A medida que a área cultivada foi sendo gradualmente ampliada, proporcional deficit de água ocorreu. Em decorrência disso, o suprimento de água foi melhorando com a construção de barragem e canais de irrigação, e o comportamento hidrológico do pântano alterou-se consideravelmente.

A vegetação paludosa, que ocorre em todos seus estágios de desenvolvimento, desđe vegetação paludosa aberta e herbácea até floresta de dois estratos, é limitada por restingas pantanosas e florestas de tesos.

Nos últimos anos, cerca de $15 \mathrm{~km}^{2}$ de floresta brejosa e cerca de $60 \mathrm{~km}^{2}$ de matagal pantanoso, vegetação subflorestal e florestal foram inundados ou severamente influenciados pela elevação extraordinária do nível das águas. Há indícios de que a floresta brejosa seja substituída por certos tipos de floresta pantanosa. Na área subflorestal pantanosa, severamente afetada pela inundação, a cama- da herbácea desapareceu (a regeneração natural das árvores incluida), enquanto a camada arbustiva foi parcialmente alagada. As árvores morreram. caíram ou permaneceram desfolhadas durante as grandes inundações. Na superfície aberta de água entre essas árvores, desenvolveu-se uma densa camada de plantas aquáticas. Nas turfas flutuantes e madeiras mortas, formou-se uma nova vegetação pantanosa herbácea, tolerante à luz. Em alguns casos, árvores de pântano desenvolveram novas brotaçōes dos troncos e raízes, enquanto uma das espécies formou raizes verdadeiras a partir de raízes respiratórias suberosas.

A sucessão vegetacional, acompanhada de acumulação de turfa, continuará se processando enquanto permaneceram altos os níveis do pântano no futuro. Para que a capacidade de armazenamento do pântano não decresça, é aconselhável manejar o nivel das águas do pântano de tal modo que não permita futura alagação da vegetação paludícola lenhosa durante os períodos úmidos, e que, também, permita a aeração da camada turfosa durante o período seco.

São apresentadas tabelas das modificaçōes iniciais ocorridas após a inundação e um mapa da ve getação e de muđança de vegetação.

\section{LITERATURE CITED}

BRAAK, C.

1935 - The climate of the Netherlards West Indies. Meded. Kon. Ned. Meteor. Inst., $36: 120 \mathrm{p}$.

BRINKMAN, R. \& PONS, L.J.

1968 - A pedo-geomorphological classification and map of the Holocene sediments in the coastal plain of the three Guianas. Soil Survey Paper 4. Wageningen, Netherlands Soil Survey Institute. 40 p.

BubBerman, F.C.

1973 - De bosbranden van 1964 in Suriname. Nw. W. I. Gids, $49: 163-173$.

Central bureau for Aerial Survey, Suriname. Aerial photographs (verticals) Sscale $1: 20.000,1947 / 49 / 72$ - resp. $1: 30.000$ of the northern Nanni basin.

1972 - Topographic Maps, scale 1:100.000, nrs. $1,2,9,10.5$ th print.

EYK, J.J. VAN DER

1954 - The landscapes of Northern Surinam (Dutch with English summary). Publ. Centr. Bur. Luchtkaart., Paramaribo, 15:22.

1957 - Reconnaissance soil survey in Northern Surinam. Thesis Wageningen. 
GeiJskes, D.C.

1941 - De Nannikreek. Reisverslag en resultaten van een biologisch orderzoek. Unpubl. report. Paramaribo. $45 \mathrm{p}$.

1942 - Verslag van twee vliegtochten boven de Nannikreek in Nickerie op 18 september. Unpubl. report Paramaribo. 13p.

1945 - Plants of the Surinam Coastland. Some observations on the littoral vegetation of Dutch Guiana. Journ. N.Y. Bot. Garden, 46:229-236.

1946 - Schetskaart (schaal 1:200.000) van de vegetatie in het stroomgebied van de Nannikreek. Unpubl. map. Paramaribo.

1973 - Reisverslag van de Expeditie West Suriname 1971. Zool. Bijdr. Leiden, 15:1-41.

GeiJskes, D.C. \& SCHOLs, H.

1948 - Topografische observaties bij twee verkenningsvluchten boven Noordelijk Suriname. Tijdchr. K. N. A. G. ser. 2, 65:342-353.

Lanjouw, J.

1936 - Studies of the Suriname savannahs and swamps. Ned, Kruidk. Arch., 46:823-851.

LINDEMAN, J.C.

1953 - The vegetation of the coastal region of Suriname. The Veg. of Sur. I.1. Meded. Bot. Mus. Herb. Utrecht, 113:1-135.

Lindeman, J.C. \& MoOlenaAR, S.P.

1955 - Voorlopig overzicht van de bostypen in het noordelijk deel van Suriname. $\mathrm{Pa}$ ramaribo, Ed. Surinam Forest Service. $55 \mathrm{p}$.
1959 - Preliminary survey of the vegetation types of northern Surinam. The veg. of Sur. I. 2. Meded. Bot. Mus. Herb. Utrecht, 159:1-45.

Metereological Service, Suriname

1960 - Precipitation maps and Climatological tables. Paramaribo.

OSTENDORF, F.W.

1953/57 - Ons klimaat 1-8. De sur. Landbouw $1-5$.

PONS, L.J.

1964 - Rapport bij een geomorfologische bodemkaart van de kustvlakte van Suriname. Schaal 1:500.000. Soil Survey Department, report, 14-3:1-19.

1966 - Geogenese en pedogenese in de jong. -holocene kustvlakte van de drie Guianas. Tijdschr. K.N.A.G., (2):153-172.

SEVENHUYSEN, R.J.

- Hydrological behaviour of shallow lakes and marshes in small watersheds in the humid tropics, with special referen. ce to the Nanni Swamp in Suriname (in preparation).

SCHULz, J.P

1960 - Ecological studies on rain torest in northern Suriname. The Veg. of Sur. II. Verhand. Kon. Ned. Akad. Wetensch ard. Natuurk. ser. 2., 53(1):1-267 Meded. Bot. Mus. Herb. Utrecht, 163.

SoIL SuRvey Department, Suriname

1964 - Overzichts-bodemkaart Henar-Maratakka (Cupido) District Nickerie, schaal 1:10.000. Paramaribo. 


\section{APPENDIX}

\section{LIST OF SPECIES MENTIONED IN TEXT AND TABLES}

A preliminary list of species of the northern Nanni Swamp based on herbarium specimens, literature and sight records is available on request from the Herbarium of the Suriname Forest Service, P. O.B. 436, Paramaribo, Suriname.

\section{PTERIDOPHYTA}

\section{Parkeriaceae}

Ceratopteris thalictroides (L.) Brongn.

Polypodiaceae

Acrostichum aureum L.

Acrostichum danaeifolium Langsd, et Fish.

Blechnum serrulatum L.C. Rich.

Nephrolepis biserrata (Sw.) Schott

Polypodium ciliatum Willd.

Tectaria incisa Cav.

Thelypteris serrata (Cav.) Alston

Salviniaceae

Azolla caroliniana Willd.

Salvinia auriculata Aubl.

\section{SPERMATOPHYTA}

Acanthaceae

Dianthera obtusifolia (Nees) Griseb.

Anacardiaceae

Spondias mombin L.

Annonaceae

Annona glabra L.

Apocynaceae

Allamanda cathartica $\mathrm{L}$.

Bonafousia tetrastachya (H.B.K.) Mgf.

Araceae

Anthurium sp.

Monstera cf. expilata Schott

Monstera obliqua Miq.

Monstera pertusa (L.) De Vriese

Monstera sp. (L.B.B. 14472)

Montrichardia arborescens (L.) Schott

Pistia stratiotes L.

Philodendron cf. acutatum Schott

Philodendron jenmannii Krause

Philodendron linnaei Kunth

Philodendron pedatum (Hook.) Kunth

Syngonium vellozianum Schott var. poeppigii Eng.

Asclepiadaceae

Funastrum" clausum (Jacq.) Schltr.

Avicenniaceae

Avicennia nitida Jacq.
Bignoniaceae

Macfaydena uncata (Andr.) Sprague et Sandw

Tabebuia insignis. group

$\Gamma$ Tabebuia aquatilis

(E. Mey.)

Sprague et Sandw.

Tabebuia insignis

(Miq.)

Sandw. var. menophyla

Sandw.

Tabebuia serratifolia (Vahl) Nicholson

Bombacaceae

Ceiba pentandra Gaertn.

Boraginaceae

Cordia tetrandra Aubl.

Clusiaceae

Symphonia globulifera L.f.

Compositae

Eclipta alba (L.) Hasskarl

Mikania congesta DC.

Mikania micrantha H.B.K.

Pluchia odorata (L.) Cassini

Wulffia baccata (L.f.) O. Kuntze

Comp, nr. VIII

Comp. nr. XII

Convolvulaceae

Ipomoea phillomega House

Ipomoea subrevoluta Choisy

Ipomoea tiliacea Choisy

Cyperaceae

Cyperus articulatus L.

Cyperus haspan L.

Cyperus comosus Poir.

Cyperus giganteus Vahl

Cyperus pseudodistans Uitt.

Scirpus cubensis Poepp. ex Kunth

Scleria eggersiana Boeck.

Cucurbitaceae

Gurania spinulosa (Poepp. et Endl.) Cogn.

Melothria fluminensis Gardn.

Dilleniaceae

Dill. nr. III

Dill, nr, XVIII

Dioscoreaceae

Diosc. nr. XXVII

Euphorbiaceae

Omphalea diandra $\mathrm{L}$.

Gramineae

Hymenachne amplexicaulis (Rudge) Nees

Leersia hexandra Sw

Luziola spruceana (Benth, ex Doell)

Panicum frondescens G.F.W. Mey.

Panicum grande Hitchc, et Chase

Sacciolepis striata (L.) Nash 
Lecythidaceae

Gustavia augusta Alm. sensu Berg

Eschweilera sp.

Lemnaceae

Lemna minor $\mathrm{L}$.

Lemna perpusilla Torrey

Spirodela biperforata Koch

Wolfiella lingulata (Hegelm.) Hegeimaier

Lentibulariaceae

Lentibulariacea spp.

Loranthaceae

Phthirusa seitzii Krug et Urb.

Malvaceae

Hibiscus bifurcatus Cav.

Hibiscus sororius L.f.

Hibiscus tiliaceus L.

Marantaceae

Calathea legrelleana Regel

Ischnosiphon vs, violaceus Pulle (LBB 14504)

Ischnosiphon $\mathrm{sp}$.

Marcgraviaceae

Marcgravia coriacea Vahl

Meliaceae

Carapa procera DC.

Cedrela odorata $\mathrm{L}$.

Trichilia sp. nr. IV

Menyanthaceae

Nymphoides humboldtianum (H.B I .) O.K.

Mimosaceae

Entada polytachya (L.) DC.

Inga ingoides (L. C. Rich.) Willd.

Inga sp.

Moraceae

Cecropia obtusa Trèc.

Ficus citrifolia P. Miller

Ficus sp. (LBB 14959)

Musaceae

Heliconia bihai L.

Heliconia cf. caribaea Lam.

Heliconia marginata (Griggs) Pittier

Heliconia psittacorum L.f.

Heliconia sp. nov. (LBB 14484)

Myristicaceae

Virola surinamensis (Rol.) Warb.

Nymphaeaceae

Nymphaea blanda G.F.W. Meyer var fenzliana (Lehm.) Casp.

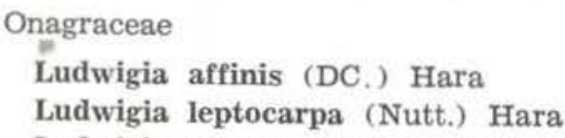

Palmae

Attalea maripa Mart.

Bactris sp.

Desmoncus sp.

Euterpe oleracea Mart.

Papilionaceae

Aeschynomene sensitiva Swartz

Dioclea virgata (L.C. Rich.) Amsh.

Erythrina glauca Willd.

Machaerium lunatum (L.) Ducke

Mora excelsa Benth.

Phaseolus campestris Mart. ex Benth.

$=\mathrm{P}$. juruanus Harms

Pterocarpus officinalis Jacq.

Swartzia arborescens (Aubl.) Pittier

Papil. nr. II

Piperaceae

Peperomia elongata H.B.K. var. piliramea Trel, et Yunk.

Piper divaricatum G.F.W. Mey.

Piper aequale Vahl

Polygonaceae

Cossoloba latifolia Lam.

Triplaris surinamensis Cham.

Rhizophoraceac

Rhizophora mangle $\mathrm{L}$

Rubiaceae

Palicourea crocea (Sw.) DC

Rub. nr. XIII

Sapindaceae

Paullinia pinnata $\mathrm{L}$.

Talisia sp. (LBB 14491)

Sapotaceae

Manilkara bidentata (A.DC.) Chev.

Solanaceae

Solanum stramonifolium Jacq.

Theophrastaceae

Clavija lancifolia Desf.

Typhaceae

Typha angustifolia $\mathrm{L}$.

Umbelliferae

Hydrocotyle umbellata L.

Violaceae

Rinorea pubiflora

$(=$ R. passoura (DC.) O.K. )

Vitaceae

Cissus erosa L.C. Rich.

Cissus sicyoides L.

Xyridaceae

Xyris macrocephala Vahl

Zingiberaceae

Costus arabicus $\mathrm{L}$.

Indet :

nr. XXIII 


\section{TREE LAYER}

coverage height

Pterocarpus officinalis

Tabebuia insignis var. monophylla Monstera obliqua

Monstera cf. expilata (nr. 14460)

Philodendron linnaei

Philodendror cf. acutatum

Philodendron pečatum

Philodendron jenmannii

Syngonium vellozianum var. poepp.

Euterpe oleracea

Entada polystachya

Ficus sp. (nr. 14959)

Triplaris surinamensis

Cecropia obtusa

Virola surinamensis

SHRUB LAYER

Montricharidia arborescens

Peperomia elongata var. pil.

Niarcgravia coriacea

Costus arabicus

Acrostichum danaeifolium

Thelypteris serrata

Piper divaricatum

Liane indet. (XXIII)

\section{HERB LAYER}

Panicum frondescens

Nephrolepis biserrata

Pauilinia pinnata

Euterpe oleracea

Polypodium ciliatum

Cissus sicyoides

Lianes, $4 \mathrm{spp}$. indet (Comp. VIII, XII; Dill. XVIII; Diose. XXVII) tr

tr

ep

ep

ep

ep

c1p

ep

ep

pm

li

ti

tr

$\mathrm{tr}$

tr

coverage

height

gh

ep

ep

gh

fe

fe

sh

li

coverage

height

gr

fe

vi

pm

ep

vi

li

(") - For notes and observations of December 1974 see text "Vegetation Chauges" 
Hibiscus bifurcatus

sh

Mikania micrantha

Mikania congesta

Solanum stramonifolium

Pluchea odorata

Dianthera obtusifolia

Nephrolepis biserrata

Ludwigia affinis

Luziola spruceana

Hymenachne amplexicaulis

Cyperus haspan

Cyperus pseudodistans

Phaseolus campestris

Melothria fluminensis

\section{AQUATIC PLANTS}

Pistia stratiotes

Spirodela biperforata

Lemna minor

Nymphaea blanda var. fenzliana

Azolla caroliniana

Ceratopteris thalictroides

Wolfiella lingulata

vi

vi

sh

he

he

fe

he

gr

gr

gr

gr

vi

vi

aq

ac

aq

aq

aq

aq

$\mathrm{aq}$ coverage

height

TABLE B (")

LOW PTEROCARPUS-TABEBUIA

SWAMP WOOD

\section{TREE LAYER}

Pterocarpus officinalis

Tabebuia insignis var. monophylla

Monstera sp. (nr. 14472)

\section{SHRUB LAYER}

Montrichardia arborescens

Acrostichum danaeifolium

\section{HERB LAYER}

Heliconia psittacorum

Ischnosiphon sp.

Blechum serrulatum

Nephrolepis biserrata $\operatorname{tr}$

tr

ep

gh

fe

he

he

fe

$\mathrm{fe}$

$\begin{array}{lrl}\begin{array}{l}\text { date } \\ \text { plot }\end{array} & \begin{array}{r}\text { Oct. } \\ \text { Bn }\end{array} & \begin{array}{c}1973 \\ \text { Bs }\end{array} \\ \begin{array}{l}\text { coverage } \\ \text { height }\end{array} & 90 \% & 10 \% \\ & 6.8 \mathrm{~m} & 6.8 \mathrm{~m}\end{array}$

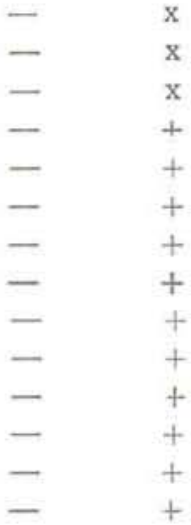

$5 \% \quad 80 \%$

$5 \mathrm{~cm} 10 \mathrm{~cm}$

$+\quad \mathrm{D}$

+ va

$+x$

$+\quad-$

- +

(") - For notes and observations of December 1974 see text "Vegetation Changes". 
coverage

height

Mikania micrantha

Phaseolus campestris

Lndwigia affinis

Ipomoea tiliacea

Thelypteris serrata

Hibiscus bifurcatus

Phthirusa seitzii

Ficus citrifolia

vs, Funastrum clausum (nr. 14481)

Paullinia pinnata

Aeschynomene sensitiva

\section{AQUATIC PLANTS}

Pistia stratiotes

Wolfiella lingulata

Azolla caroliniana

Salvinia auriculata

Lemna minor

Ceratopteris thalictroides coverage height

$\mathrm{aq}$
$\mathrm{aq}$
$\mathrm{aq}$
$\mathrm{rq}$
$\mathrm{aq}$
$\mathrm{aq}$

TABLE C ( date
plot

coverage height

tr

tr

Cecropia obtusa

Diociea virgata

SHRUB LAYER

Montrichardia arborescens

Erythrina glauca

Heliconia marginata

Costus arabicus

HERB LAYER

\begin{tabular}{|c|c|c|c|}
\hline & $\begin{array}{l}\text { date } \\
\text { plot }\end{array}$ & $\begin{array}{c}\text { Oet. } \\
\text { Cn }\end{array}$ & $\begin{array}{l}1973 \\
\text { Cs }\end{array}$ \\
\hline & coverage & $100 \%$ & $60 \%$ \\
\hline & height & $10 \mathrm{~m}$ & $10 \mathrm{~m}$ \\
\hline $\operatorname{tr}$ & & D & $\mathrm{a}$ \\
\hline $\operatorname{tr}$ & & + & + \\
\hline li & & + & - \\
\hline & coverage & $60 \%$ & $100 \%$ \\
\hline & height & $4 \mathrm{~m}$ & $4 \mathrm{~m}$ \\
\hline gh & & D & f \\
\hline sh & & $\mathrm{x}$ & $D$ \\
\hline gh & & $(x)$ & $\mathrm{x}$ \\
\hline gh & & + & - \\
\hline & coverage & $5 \%$ & - \\
\hline & height & $0,5 \mathrm{~m}$ & - \\
\hline $\mathrm{pm} / \mathrm{sl}$ & & + & - \\
\hline
\end{tabular}

Euterpe oleracea

") - For notes and observations of December 1974 see text and "Vegetation Changes". 
coverage

height

Mikania micrantha

Panicum grande

Heliconia sp. nov. (nr. 14484)

Pauilinia pinnata

Ludwigia affinis

Gurania spinulosa

AQUATIC PLANTS

Pistia stratiotes

Azolla caroliniana

Wolfiella lingulata

Salvinia auriculata coverage height

$\mathrm{aq}$

TABLE D

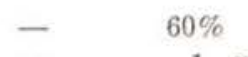

- $1 \mathrm{~m}$

$\begin{array}{ll}- & f \\ - & \mathrm{x} \\ - & + \\ - & + \\ - & + \\ - & +\end{array}$

- $\quad 10 \%$

$-\quad 5 \mathrm{~cm}$

$\begin{array}{ll}- & \mathrm{x} \\ - & \mathrm{x} \\ - & \mathrm{x} \\ - & \mathrm{x}\end{array}$

\section{MARSHY RIDGE FOREST}

UPPER TREE LAYER

Triplaris surinamensis

Ceiba pentandra

Spondias mombin

Carapa spec.

Euterpe oleracea

Dilleniacea spec. (III)

Manilkara bidentata

Inga ingoides

Talisia spec. (nr. 14491)

Trichilia spec. (IV)

Papilionacea spec. (II)

Cecropia obtusa
Attalea maripa date

plot

coverage

height

tr

$\mathrm{pm}$

tr

$\operatorname{tr}$

tr

pm

li

tr

tr

$\operatorname{tr}$

$\operatorname{tr}$

tr

$\operatorname{tr}$
Oct. 1973

De Dw

$100 \% \quad 10 \%$

$20 \mathrm{~m} \quad 20 \mathrm{~m}$

(x) $\quad x$

f f

$+\quad+$

$(+) \quad t$

$\mathrm{x}-\mathrm{t}$

f

$(+)$

$+$

+ -

$\mathrm{x}$

$\mathrm{x}$

$\mathrm{x}-1$

coverage

height

Attalea maripa

$\mathrm{pm}$

$\mathrm{tr} / \mathrm{jv}$

tr

tr

tr

tr

tr

tr

$\begin{array}{ll}\mathrm{f} & \mathrm{f} \\ \mathrm{x} & \mathrm{x} \\ + & + \\ + & + \\ \mathrm{f} & - \\ \mathrm{x} & - \\ + & - \\ + & -\end{array}$

(") - For notes and observations of December 1974 see text and "Vegetation Changos". 


$\begin{array}{lrc}\text { coverage } & 50 \% & 5 \% \\ \text { height } & 12 \mathrm{~m} & 12 \mathrm{~m}\end{array}$

Trichilia spec. (IV)

$\operatorname{tr}$

Monstera pertusa

Ipomcea phillomega

Anthurium spec.

Omphalea diandra

SHRUB LAYER

Heliconia cf. caribaea

Heliconia bihai

Piper aequale

Costus arabicus

Ipomoea phillomega

Wulffia baccata

Palicourea crocea

Ischnosiphon vs. violaceus ( $\mathrm{nr}$. 14504)

HERB LAYER (also on fallen trunks)

Caiathea legrelleana

Paullinia pinnata

Tectaria incisa

Triplaris surinamensis

Ipomoea phillomega

Ludwigia leptocarpa

Cyperus comosus

Cyperus pseudodistans

Scirpus cubensis

Mikania congesta

Solanum stramonifolium

Eclipta alba

Ludwigia affinis

Luziola spruceana

Gurania spinulosa

Piper aequale

Dioclea virgata

Cissus erosa

Cissus sicyoides

Macfadyena uncata

AQUATIC PLANTS

Pistia stratiotês

Azolla caroliniana

Spirodela biperforata coverage

height

gh

gh

sh

gh

vi

sh

sh

gh

coverase

height

gh

he

gr

gr

gr

vi

he

he

he

gi

vi

$\epsilon p$

li.

vi

vi

vi

coverage

height

aq

aq

aq $\begin{array}{cc}+ & - \\ \mathrm{x} & - \\ - & \mathrm{x} \\ - & \mathrm{x} \\ - & +\end{array}$

$30 \% \quad 83 \%$

$3 \mathrm{~m} 1 \mathrm{~m}$

f $f$

$\mathrm{x}-$ -

$\mathrm{x}-$

$\mathrm{x} \quad-$

- a

- $\mathrm{x}$

- $\mathrm{x}$

- +

$30 \% \quad 80 \%$

$1 \mathrm{~m} \quad 1 \mathrm{~m}$

$x \quad x$

va $\mathrm{x}$

$+\quad-$

- va

-

- a

- $\mathrm{f}$

- $\mathrm{x}$

- $x$

- $x$

- 4

- +

- $\quad+$

- +

- +

-

- +

-.

- +

- +

- $\quad 5 \%$

- $5 \mathrm{~cm}$

- $\quad \mathrm{x}$

- $\mathrm{x}$

- $\mathrm{x}$ 

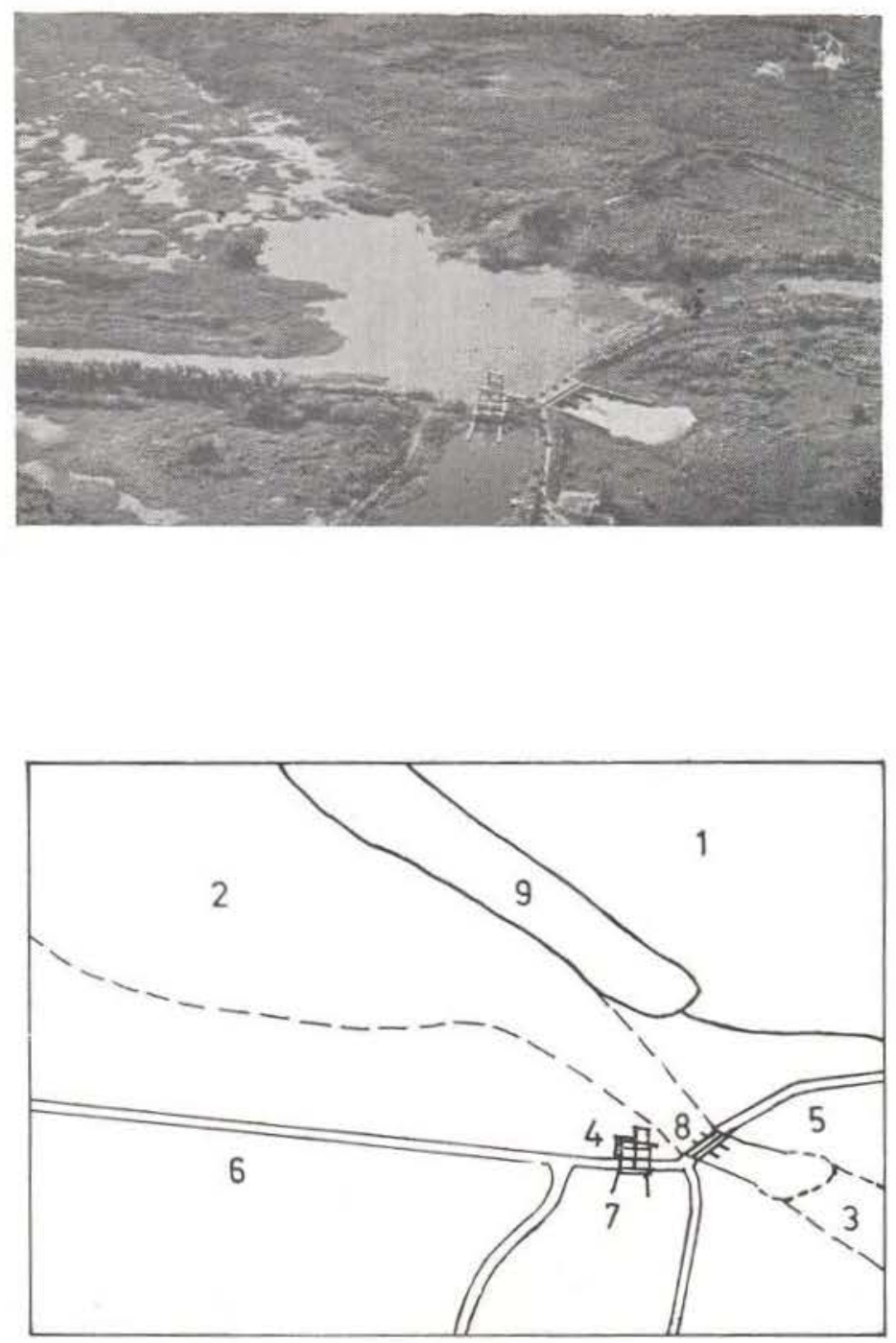

1. Nenni Swamp

2. Nanni River (upstreams)

3. Nanni River (downstreams)

4. Nanni Dam

5. Western drainage diversion dam and excavation canal

6. Southern Europolder dike and excavation canal

7. Polder inlet

8. Spillway

9. Drowned levee (formerly covered whit marsh forest). 


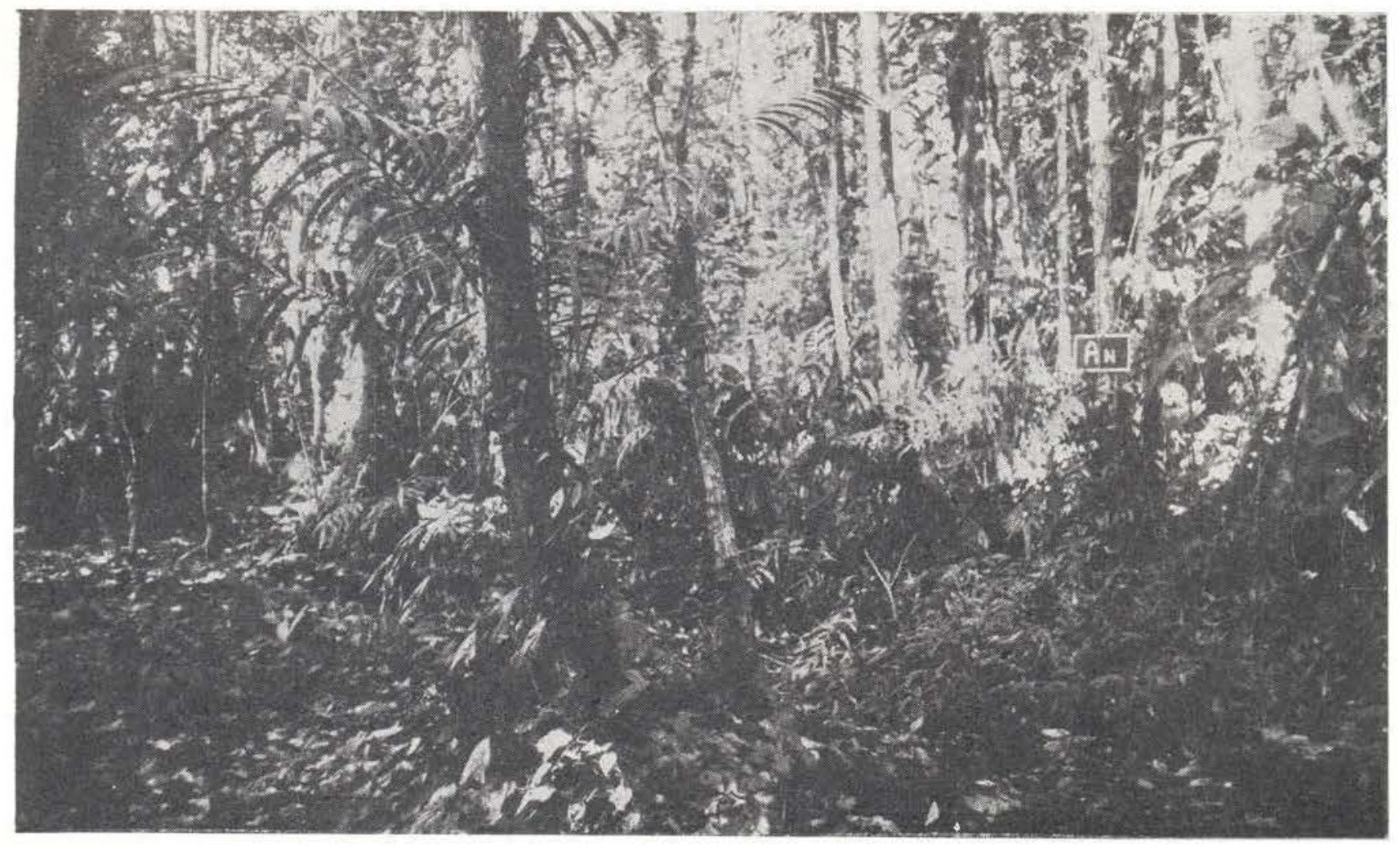

Photo 2: Pterocarpus-Tabebuia (bebe-panta) swamp wood. Plot An.

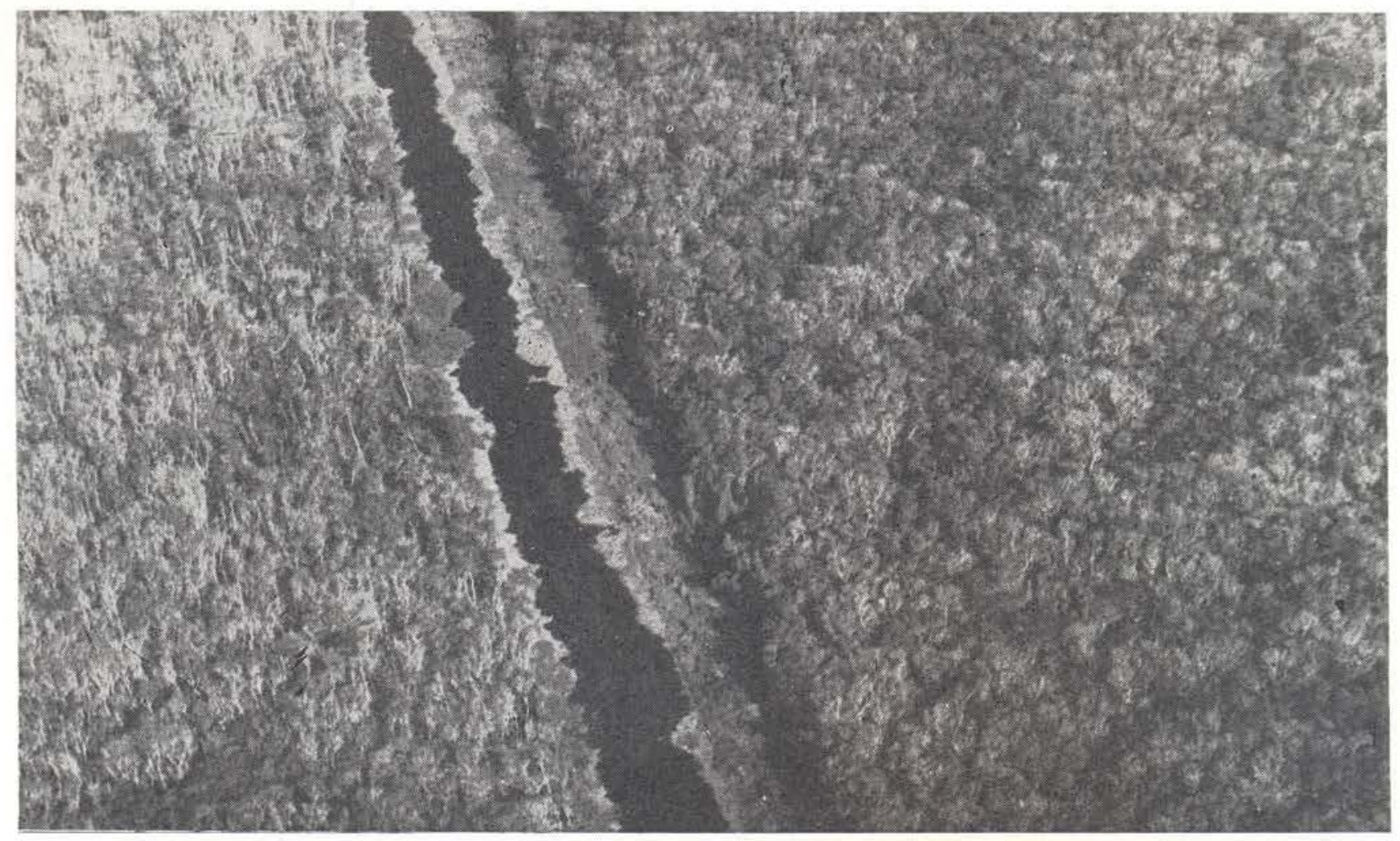

Photo 3: Oblique aerial photo of Pterocarpus-Tabebuia swamp wood Plot As (left) and An (right) October 1973. 


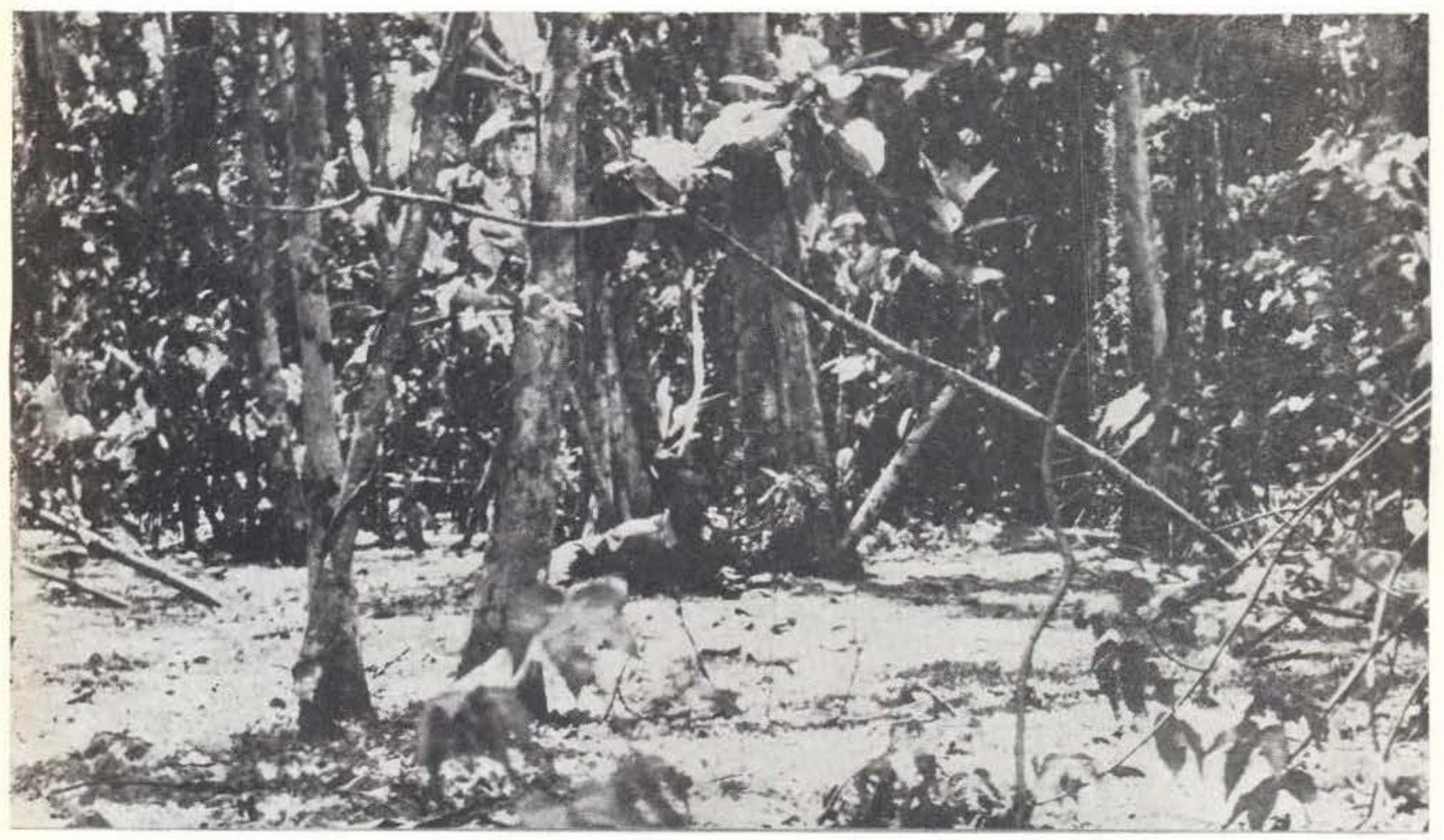

Photo 4: Pterocarpus-Tabebuia swamp wood. Plot As. September 1973. Water level at breast height. The entire water surface is covered with Pistia stratiotes and other floating aquatic plants.

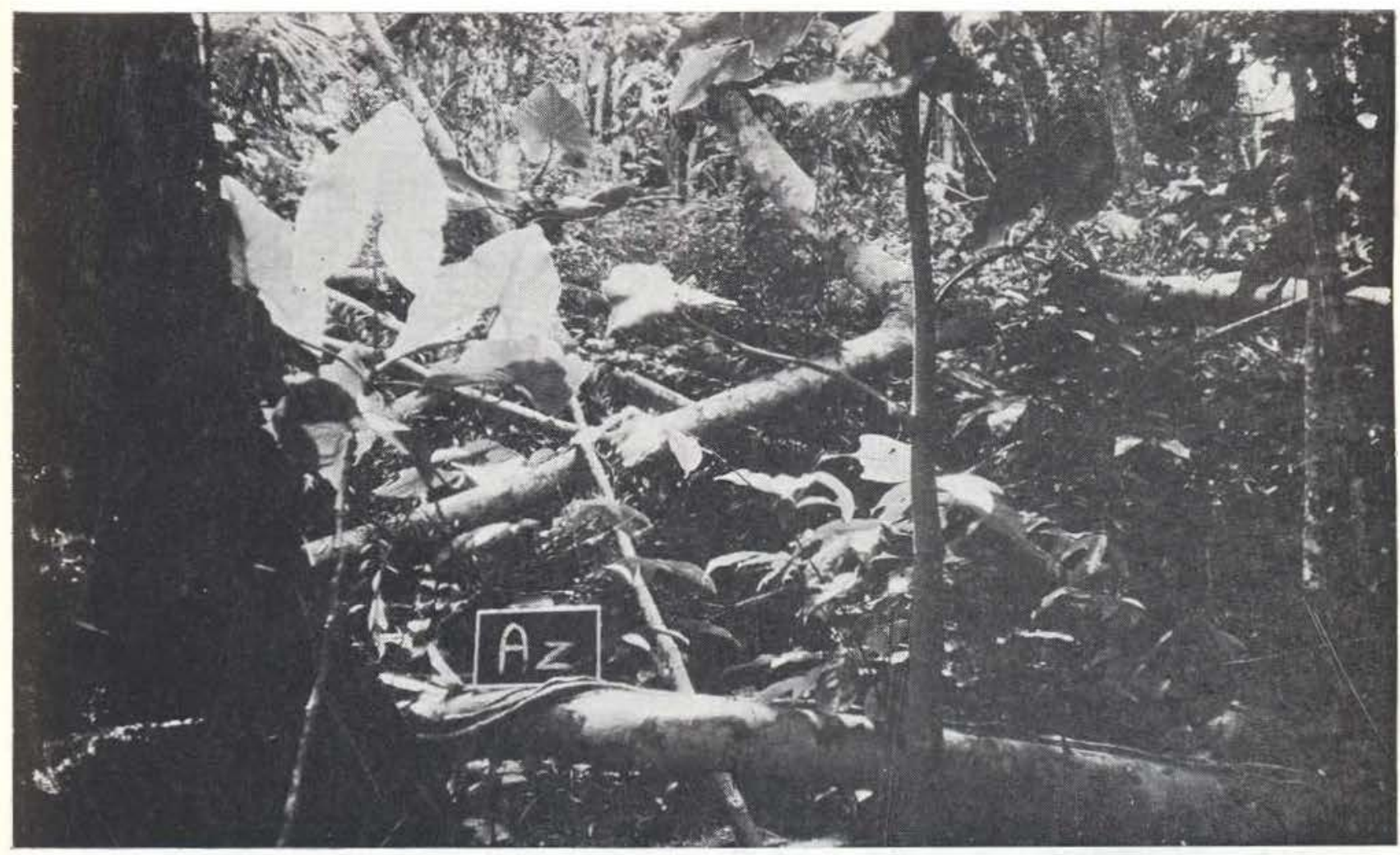

Photo 5: Pterocarpus.Tabebuia swamp wood. Plot As December 1974. About 10\% of the trees fell over during the period of observation (September 1973-December 1974). Notice the new shoots from the fallen trunk in front (Pterocarpus officinalis). 


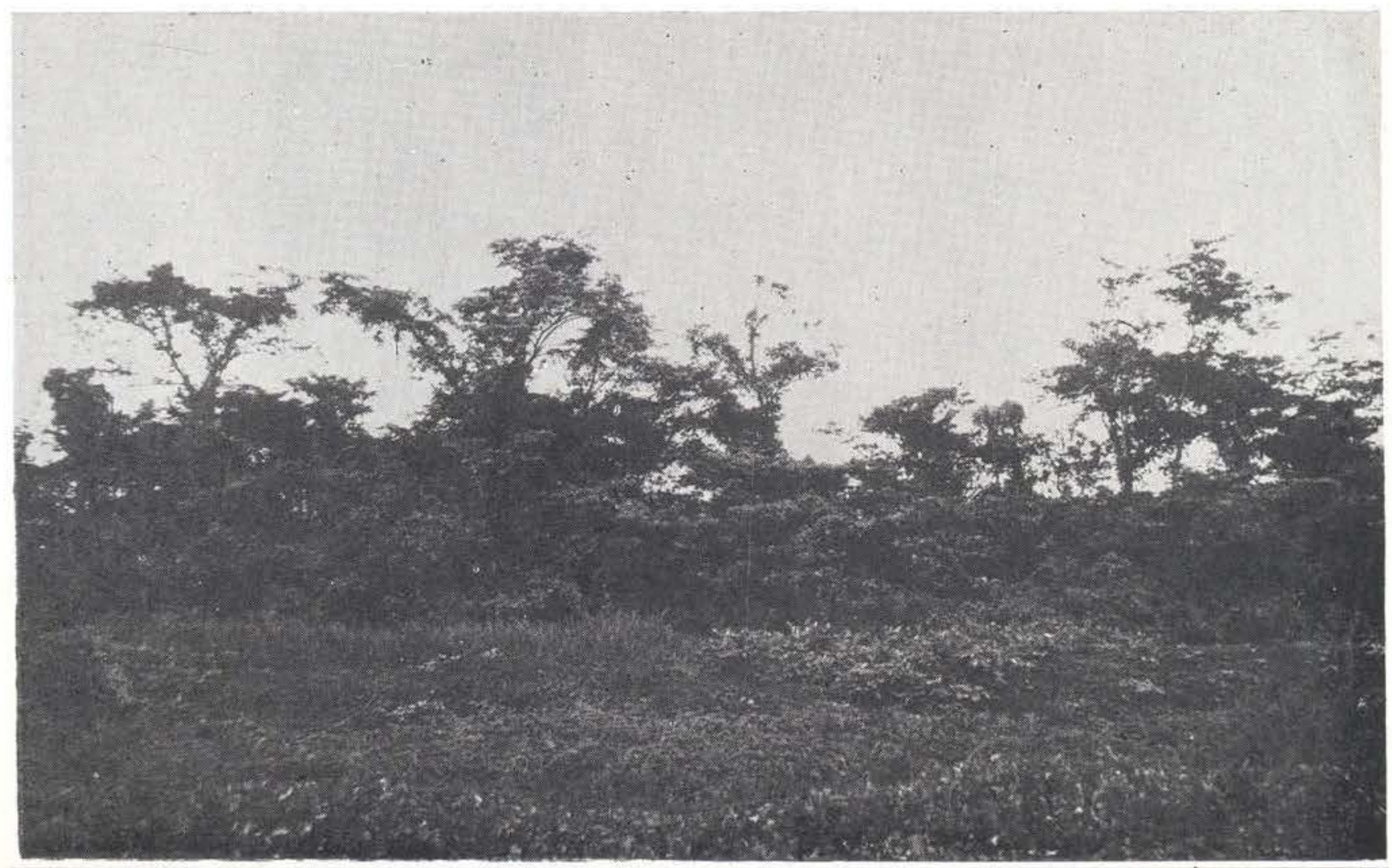

Photo 6: Young closed Pterocarpus-Tabebuia (bebe-panta) swamp wood. Plot Bn

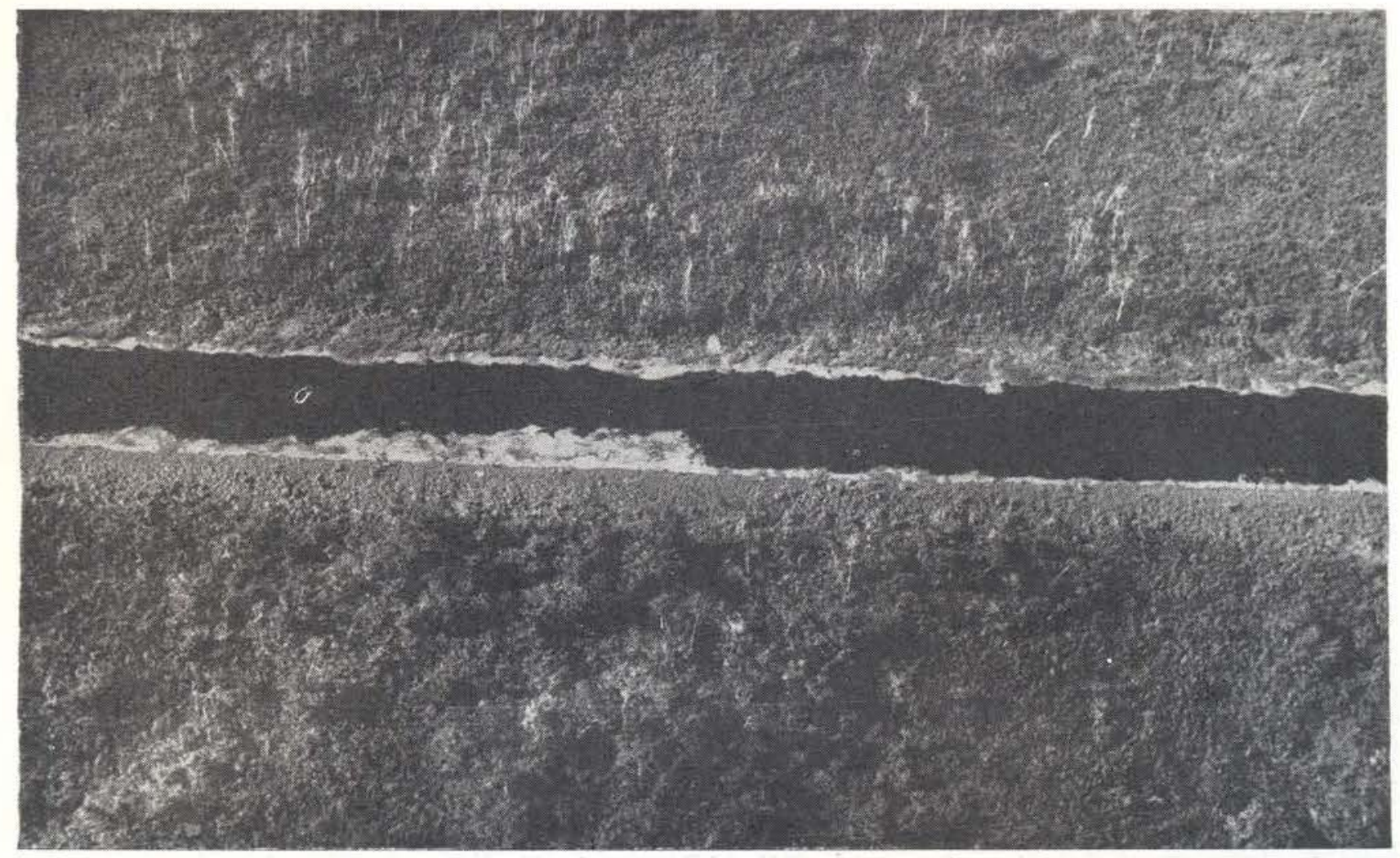

Photo 7: Oblique aerial photo of young closed Pterocarpus-Tabebuia swamp wood. Plots Bs (above) and Bn (below). Almost all treelets in plot Bs died immediately after the dam was closed. October 1973. 


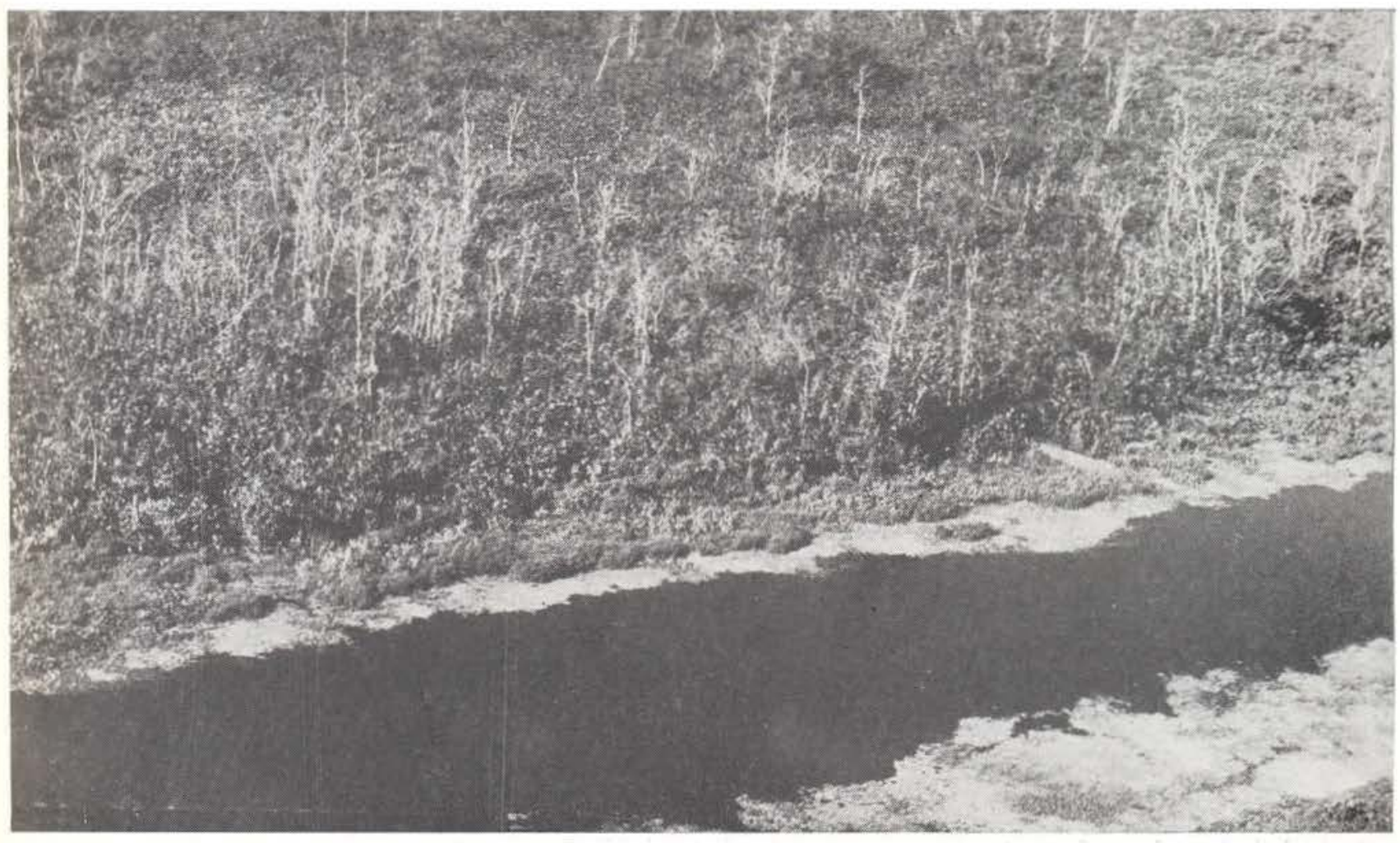

Photo 8. Drowned Pterocarpus-Tabebuia swamp wood. Plot Bs. October 1973. The closed shrub layer is mainly formed by Montrichardia arborescens (mokomoko).

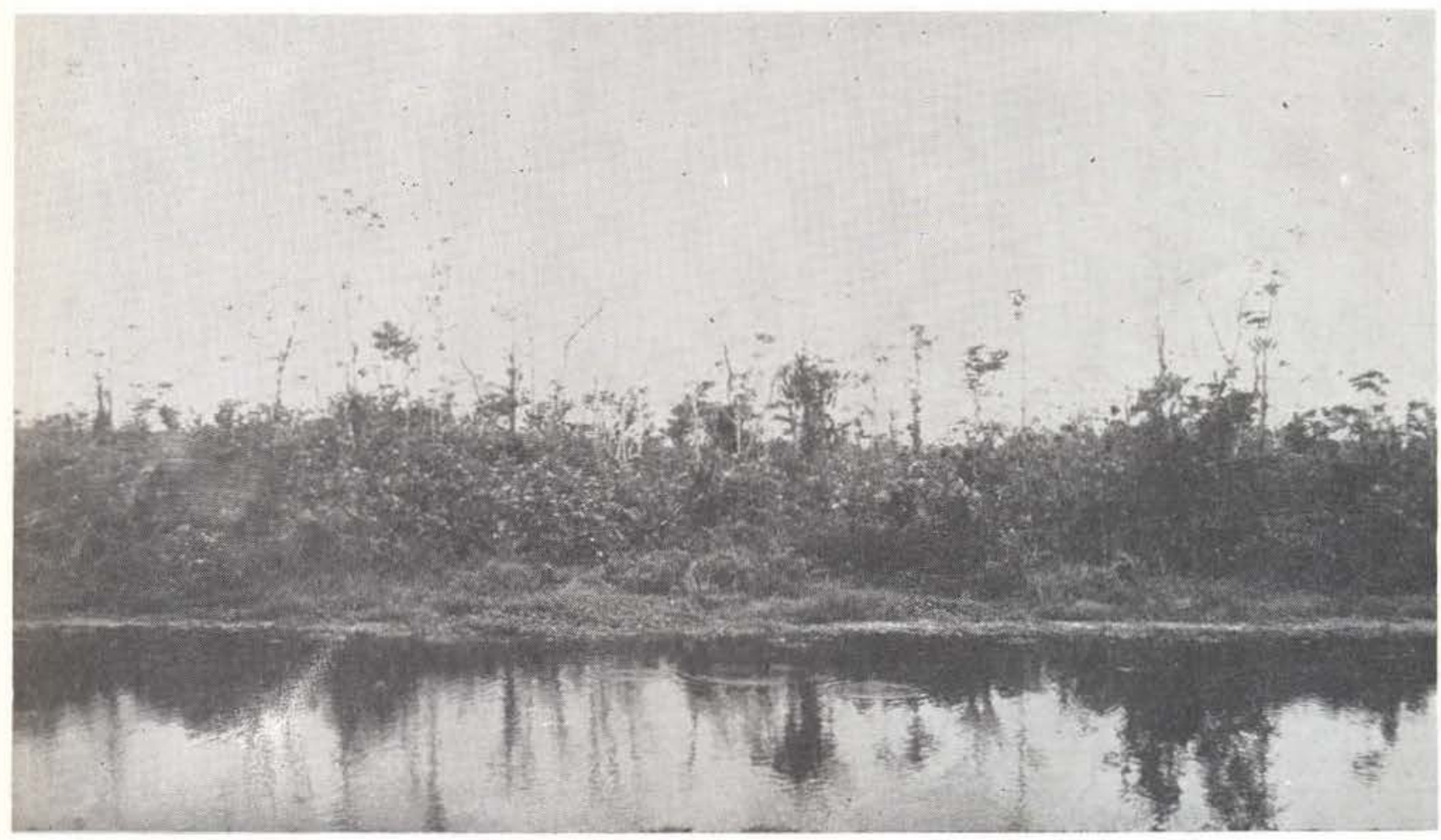

Photo 9. Drowned Pterocarpus-Tabebuia swamp wood. Plot Bs. A few treelets survived. December 1974. 


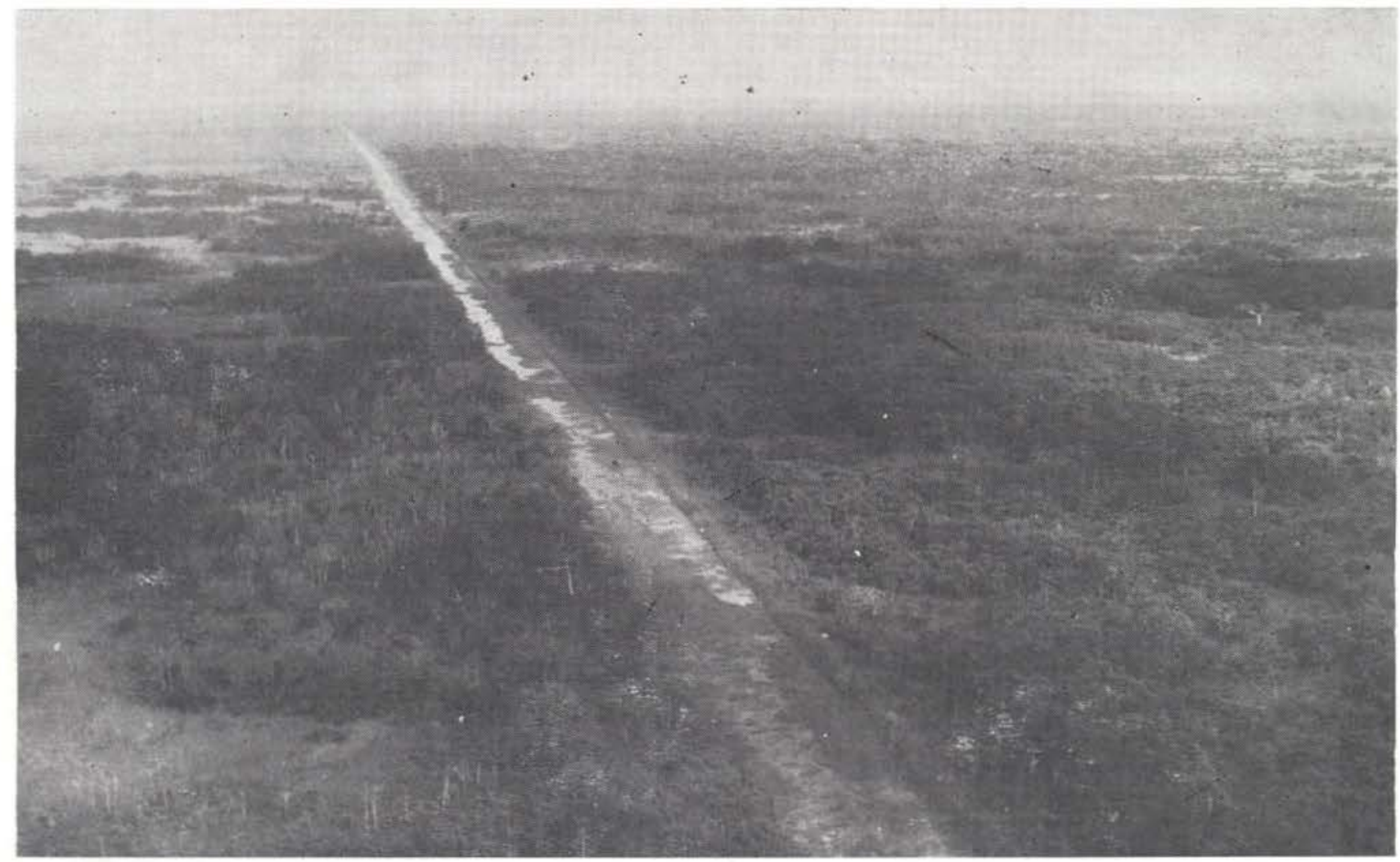

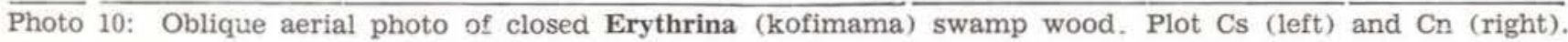
October 1973.

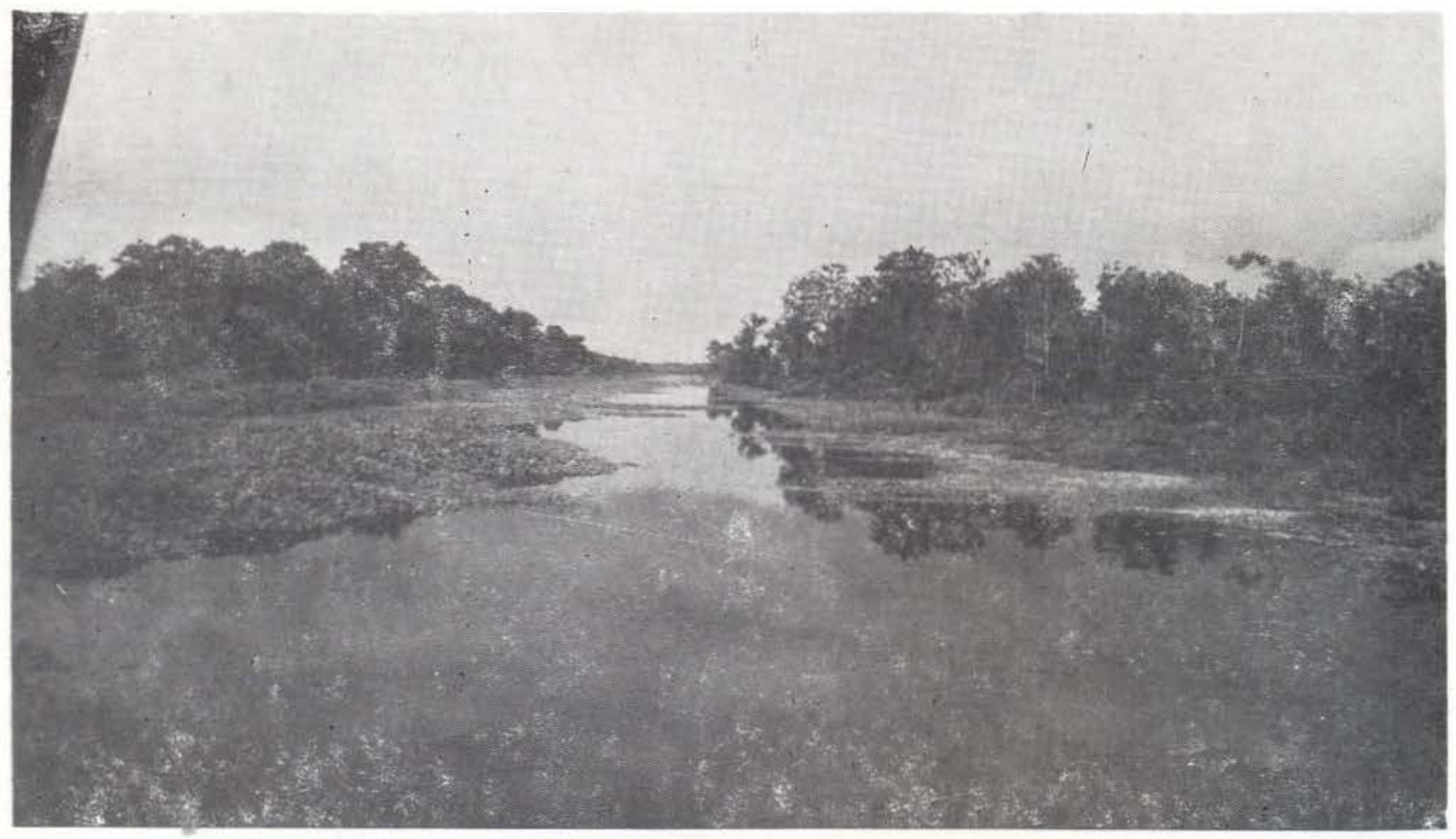

Photo 11: Closed Erythrina swamp wood in the vicinity of plots C. The swamp wood at the right suffers from the high water level. September 1973. 


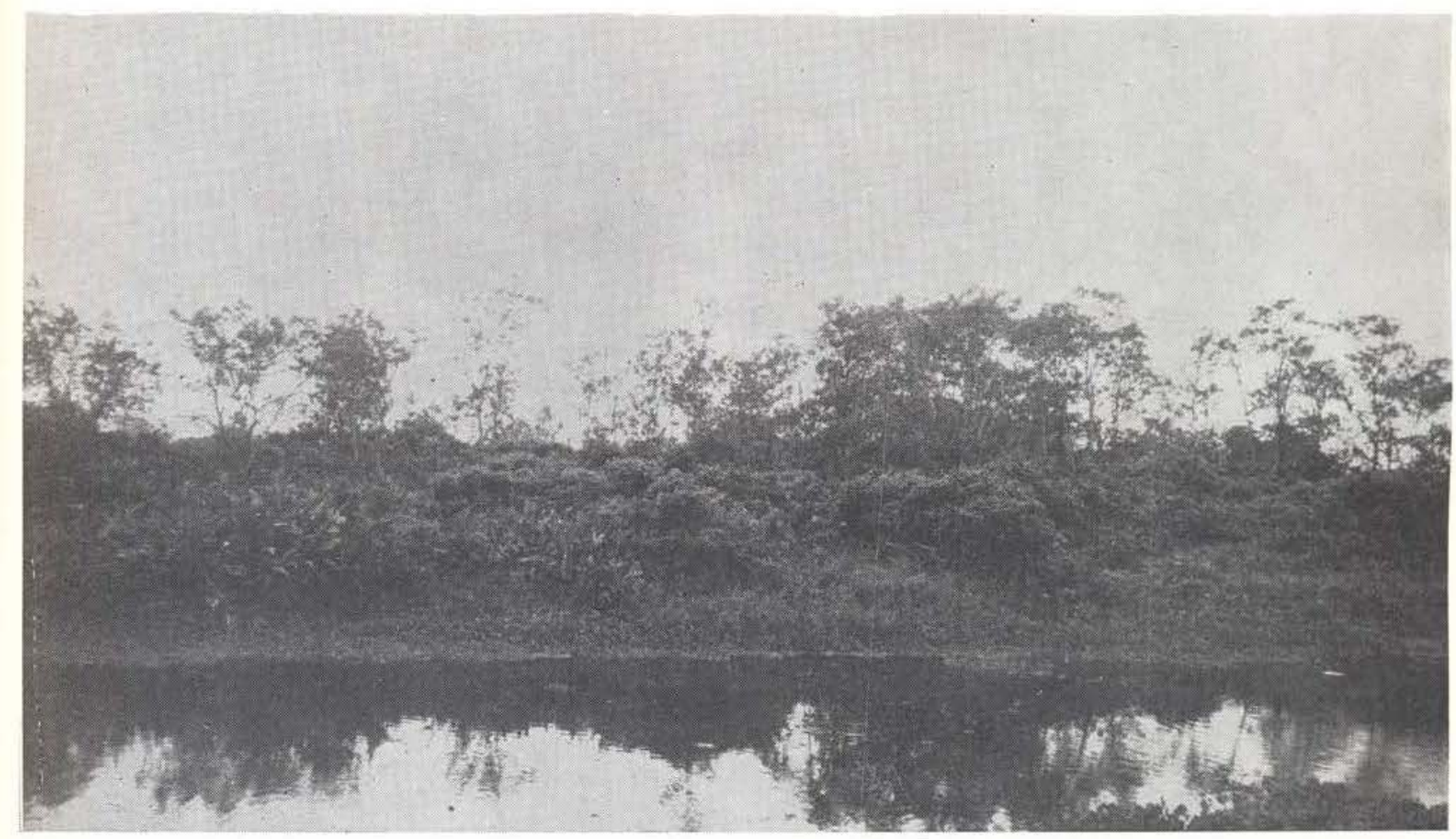

Photo 12: Erythrina swamp wood forming a new undergrowth of Erythrina scrub. P`ot Cs. December 1974.

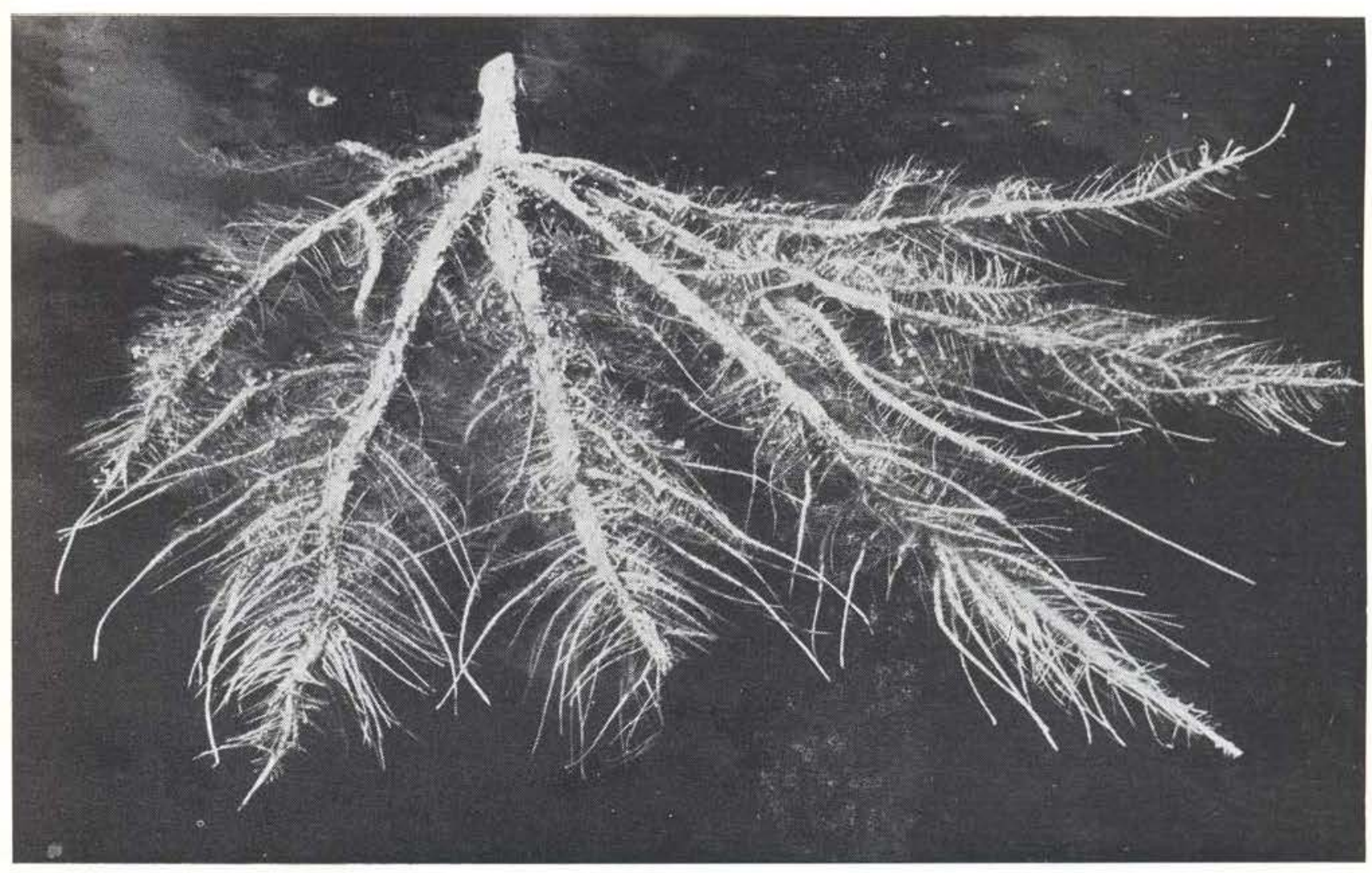

Photo 13: Cut-of corky, floating air roots as formed at the trunks of Erytimina trees at high water level. October 1973. 


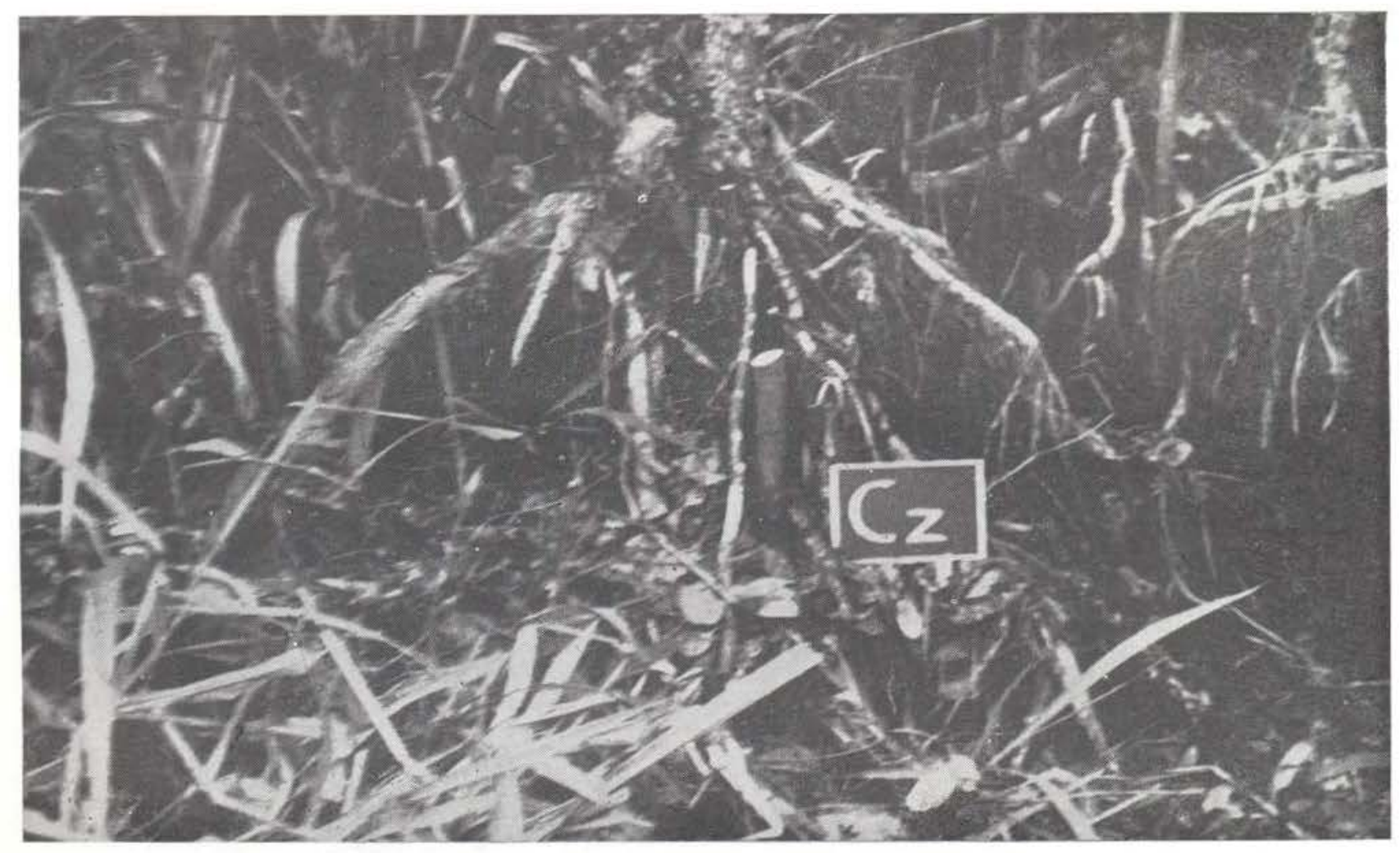

Photo 14: Erythrina swamp wood. The corky floating air roots bent down during lower water levels and eventually developed as stilt roots. Plot Cs. December 1974.

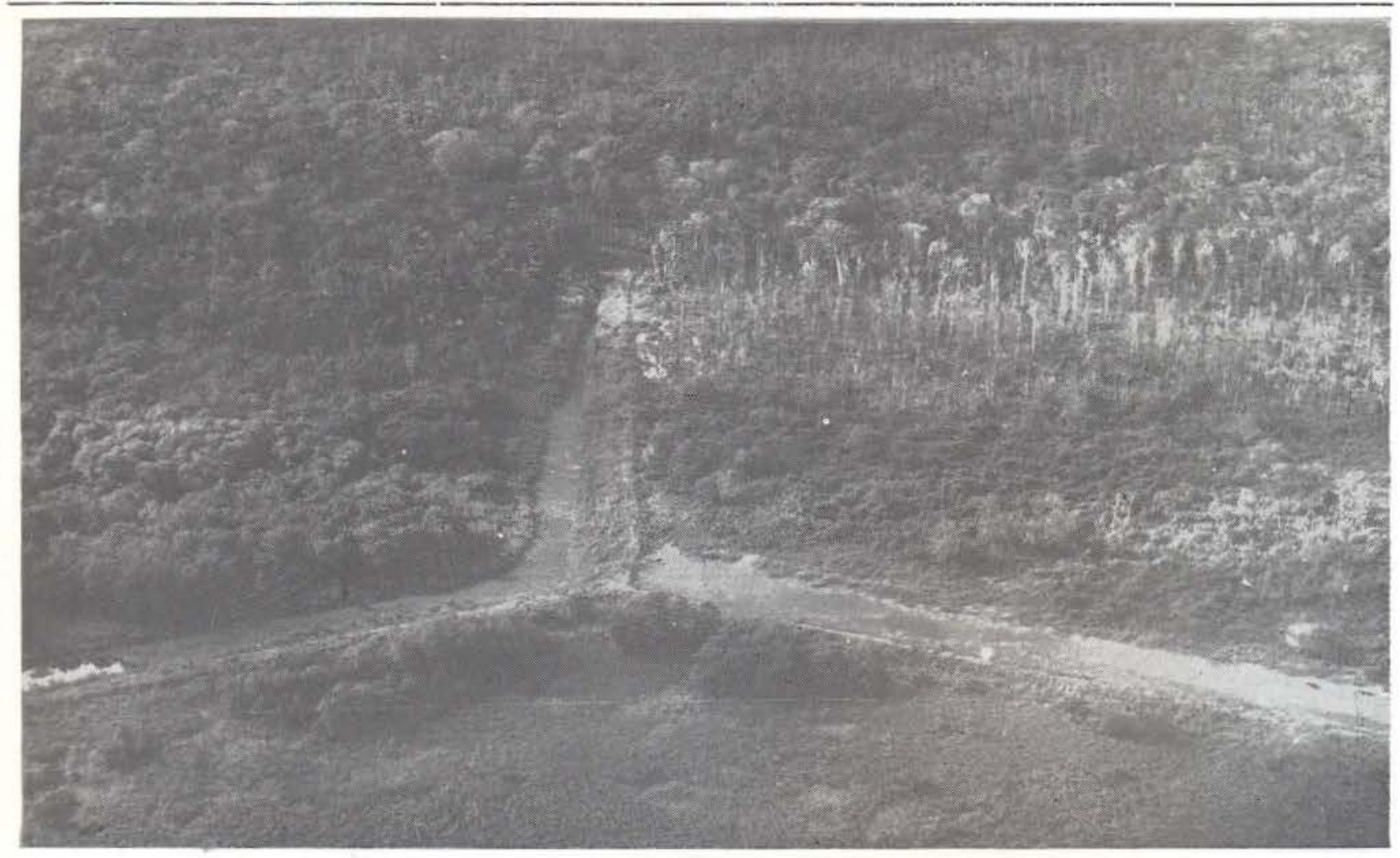

Photo 15: Oblique aerial photo of the northern edge of the Cupido ridge bundle. Plot De (left) and Dw (right), located in the marsh forest strip. 


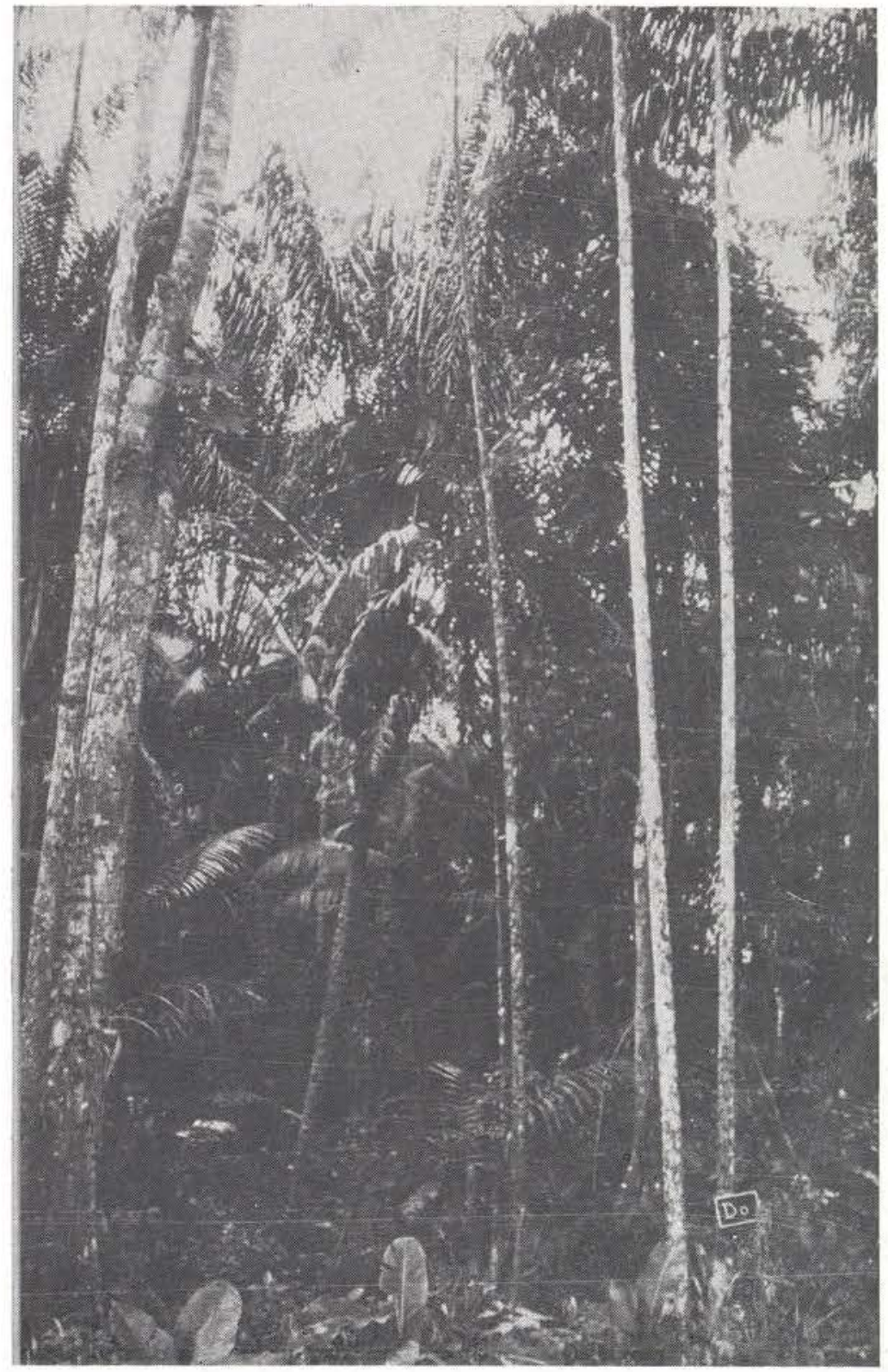

Photo 16: Marshy ridge forest Plot De. December 1974 


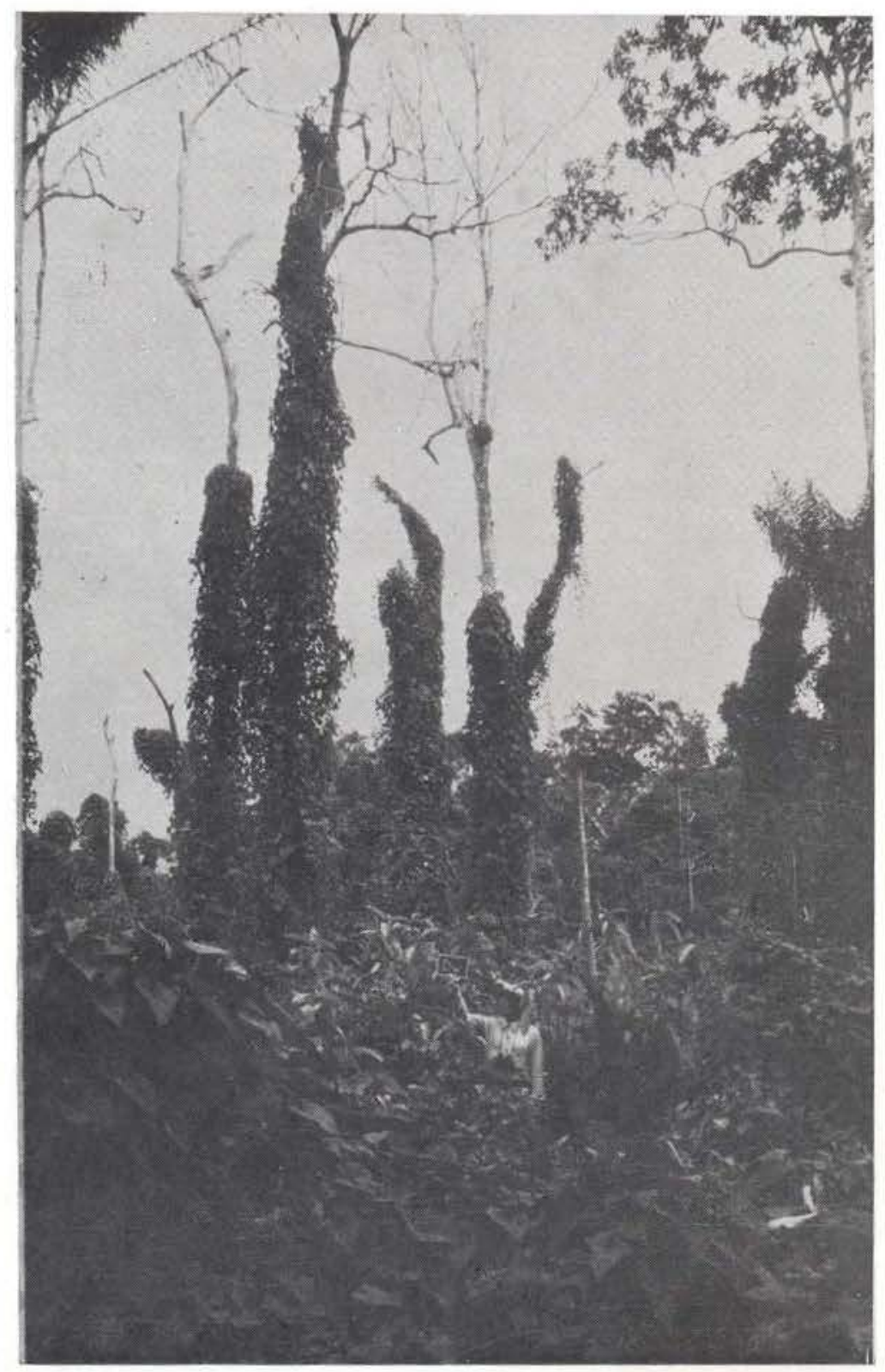

Photo 17: Drowned marsh forest. Plot Dw. December 1974. Attalea maripa (left) and Triplaris surinamensis (mira-oedoe) right, survived. The undergrowth is almost completely covered with Ipomoea phillomega (patata-tite). Only the fast growing Triplaris seedlings can compete. 


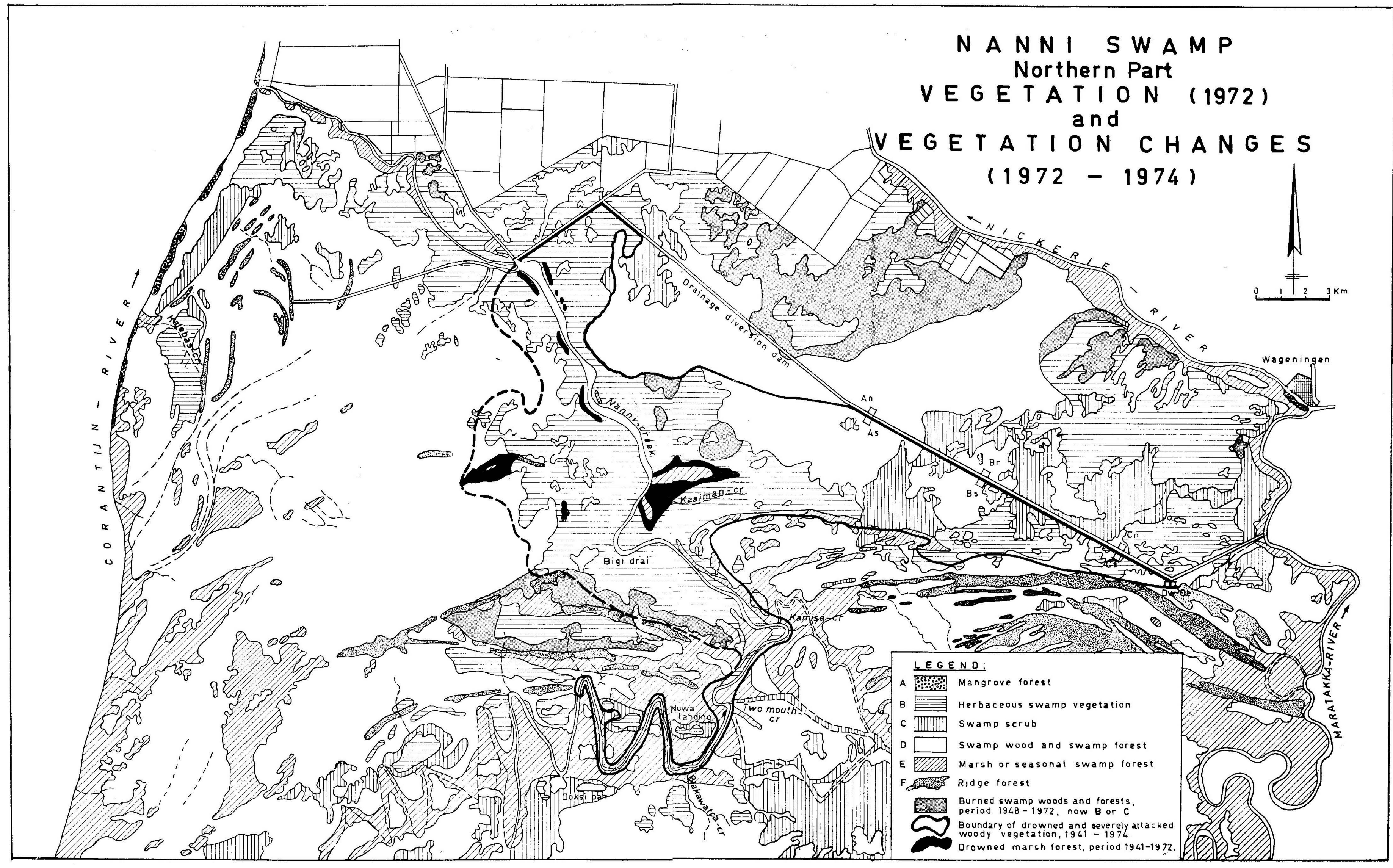

